\title{
Age, growth, and recruitment patterns of juvenile ladyfish (Elops sp) from the east coast of Florida (USA)
}

Juan C Levesque

Ladyfish (Elops sp) are a common and economically valuable coastal nearshore species found along coastal beaches, bays, and estuaries of the southeastern United States, and subtropical and tropical regions worldwide. Previously, ladyfish were a substantial bycatch in Florida's commercial fisheries, but changes in regulations significantly reduced commercial landings. Today, ladyfish are still taken in commercial fisheries in Florida, but many are also taken by recreational anglers. Life-history information and research interest in ladyfish is almost non-existent, especially information on age and growth. Thus, the overarching purpose of this study was to expand our understanding of ladyfish age and growth characteristics. The specific objectives were to describe, for the first time, age, growth, and recruitment patterns of juvenile ladyfish from the east coast of Florida (USA). In the Indian River Lagoon (IRL), annual monthly length-frequency distributions were confounded because a few small individuals recruited throughout the year; monthly length-frequency data generally demonstrated a cyclical pattern. The smallest were collected in September and the largest in May. Post-hoc analysis showed no significant difference in length between August and May, or among the other months. In Volusia County (VC), annual monthly length-frequency distribution demonstrated growth generally occurred from late-winter and spring to summer. The smallest ladyfish were collected in February and the largest in August. On average, the absolute growth rate in the IRL was $36.3 \mathrm{~mm}$ in 60 days or $0.605 \mathrm{~mm}$ day $^{-1}$. Cohort-specific daily growth rates, elevations, and coincidentals were similar among sampling years. Cohort-specific growth rates ranged from 1.807 in 1993 to $1.811 \mathrm{~mm}$ day $^{-1}$ in 1994 . Overall, growth was best (i.e., goodness of fit) described by exponential regression. On average, the absolute growth rate in VC was $28 \mathrm{~mm}$ in 150 days or $0.1866 \mathrm{~mm}^{-1 a{ }^{-1}}$. Cohort-specific daily growth rates were significantly different among sampling years; however, the elevations and coincidentals were similar. Cohort-specific growth rates ranged from 1.741 in 1994 to $1.933 \mathrm{~mm}^{-1} \mathrm{y}^{-1}$ in 1993. Mean ladyfish growth was best described by linear regression; however, natural growth was explained better by exponential regression. In the IRL, the corrected exponential growth equation yielded a size-at-age 1 of $156.0 \mathrm{~mm} \mathrm{SL}$, which corresponded to an estimated growth rate of $0.4356 \mathrm{~mm}^{2}$ day $^{-1}$. In VC, the corrected exponential growth 
equation yielded a size-at-age 1 of $80 \mathrm{~mm} \mathrm{SL} \mathrm{corresponding} \mathrm{to} \mathrm{an} \mathrm{estimated} \mathrm{growth} \mathrm{rate}$ of $0.2361 \mathrm{~mm}^{2}$ day $^{-1}$. 
1 Age, growth, and recruitment patterns of juvenile ladyfish (Elops sp) from the

\title{
east coast of Florida (USA)
}

\author{
Juan C. Levesque \\ Environmental Resources Management, 10210 Highland Manor Drive, Suite 140, Tampa, \\ Florida 33610; USA
}

\section{Abstract}

Ladyfish (Elops sp) are a common nearshore species found along coastal beaches, bays, and estuaries of the southeastern United States, and subtropical and tropical regions worldwide. Previously, ladyfish were a substantial portion of commercial landings in Florida, but changes in regulations during the mid-90s significantly reduced commercial landings of ladyfish. Today, ladyfish are still taken in commercial fisheries in Florida, but many are also taken by recreational anglers. Life-history information and research interest in ladyfish is almost non-existent, especially information on age and growth. Thus, the overarching purpose of this study was to expand our understanding of ladyfish age and growth characteristics. The specific objectives were to describe, for the first time, age, growth, and recruitment patterns of juvenile ladyfish from the east coast of Florida (USA). In the Indian River Lagoon (IRL), annual monthly lengthfrequency distributions were confounded because a few small individuals recruited throughout the year; monthly length-frequency data generally demonstrated a cyclical pattern. The smallest were collected in September and the largest in May. Post-hoc analysis showed no significant difference in length between August and May, or among the other months. In Volusia County (VC), annual monthly length-frequency distribution demonstrated growth generally occurred from late-winter and spring to summer. The smallest ladyfish were collected in February and the largest in August. On average, the absolute growth rate in the IRL was $36.3 \mathrm{~mm}$ in 60 days or $0.605 \mathrm{~mm}$ day $^{-1}$. Cohort-specific daily growth rates, elevations, and coincidentals were similar among sampling years. Cohort-specific growth rates ranged from 1.807 in 1993 to $1.811 \mathrm{~mm}$ day $^{-1}$ in 1994. Overall, growth was best (i.e., goodness of fit) described by exponential regression. On average, the absolute growth rate in VC was $28 \mathrm{~mm}$ in 150 days or $0.1866 \mathrm{~mm}$ day $^{-1}$. Cohort-specific daily growth rates were significantly different among sampling years; however, the elevations and coincidentals were similar. Cohort-specific growth rates ranged from 1.741 in 1994 to $1.933 \mathrm{~mm}^{-1 a y^{-1}}$ in 1993. Mean ladyfish growth was best described by linear regression; however, natural growth was explained better by exponential regression. In the IRL, the corrected exponential growth equation yielded a size-at-age 1 of $156.0 \mathrm{~mm} \mathrm{SL}$, which corresponded to an estimated growth rate of $0.4356 \mathrm{~mm}^{\text {day }}{ }^{-1}$. In VC, the corrected exponential growth equation yielded a size-at-age 1 of $80 \mathrm{~mm} \mathrm{SL}$ corresponding to an estimated growth rate of $0.2361 \mathrm{~mm}^{\mathrm{day}}{ }^{-1}$.

Keywords: Conservation, Life-history, Length-frequency, Petersen Method, Management 


\section{INTRODUCTION}

Ladyfish (Elops sp) are a common nearshore species found along coastal beaches, bays, and estuaries of the southeastern United States (Zale \& Merrifield, 1989; McBride et al., 2001), and subtropical and tropical regions worldwide (Ugwumba, 1989; Brinda \& Bragadeeswaran, 2005). Seven Elops species have been identified worldwide (Adams et al., 2013); two (Elops saurus and Elops smithi) are found in the western North Atlantic Ocean (McBride \& Horodysky, 2004; McBride et al., 2010; Adams et al., 2013). Ladyfish have a specialized leptocephalus larval stage (Gehringer, 1959), which is uncommon to fish; most fish do not go through a metamorphosis stage after hatching (Smith, 1989). Approximately 800 species have a leptocephalus larval stage, but most are eels (Greenwood et al., 1966; Smith, 1989). Tarpon (Megalops atlanticus) and bonefish (Albula vulpes) are the only other economically and socially valuable fish that have a leptocephalus larval stage. Tarpon and bonefish support valuable recreational fisheries in the United States, Central America, and other subtropical/tropical regions worldwide (Cooke \& Phillip, 2004; Cooke et al., 2006; Felder \& Hayes, 2008). Previously, ladyfish were a substantial portion of commercial landings in Florida, but changes in regulations during the mid-90s significantly reduced commercial landings of ladyfish (Levesque, 2011). Today, ladyfish are still taken in commercial fisheries in Florida, but many are also taken by recreational anglers (Levesque, 2011).

Understanding a species' life-history characteristics is necessary for making informed decisions and implementing successful management measures. Unfortunately, life-history information and research interest in ladyfish is almost non-existent, especially information on age and growth (Adams et al., 2013). Several brief notes (Alikunhi \& Rao, 1951; Gehringer, 1959) and studies (McBride et al., 2001; Levesque, 2014) have reported information about age 
68 and growth, but knowledge is limited, speculative, and incomplete. Although Levesque (2014)

69 described age and growth of juvenile ladyfish in Tampa (Florida), and McBride et al., (2001)

70 reported the age and growth for larger size-classes in Tampa Bay and the Indian River Lagoon,

71 these studies were somewhat restricted in terms of geography and analytical procedures.

72 Currently, there are no studies that corroborate or validate age estimates of ladyfish. Given this

73 management need, the overarching purpose of this study was to expand our understanding of

74 ladyfish age and growth characteristics. The specific objectives were to describe, for the first

75 time, age, growth, and recruitment patterns of juvenile ladyfish from the east coast of Florida

76 (USA).

77

\section{MATERIAL AND METHODS}

79

80

81

82

83

84

85

86

87 (Levesque, 2013). 


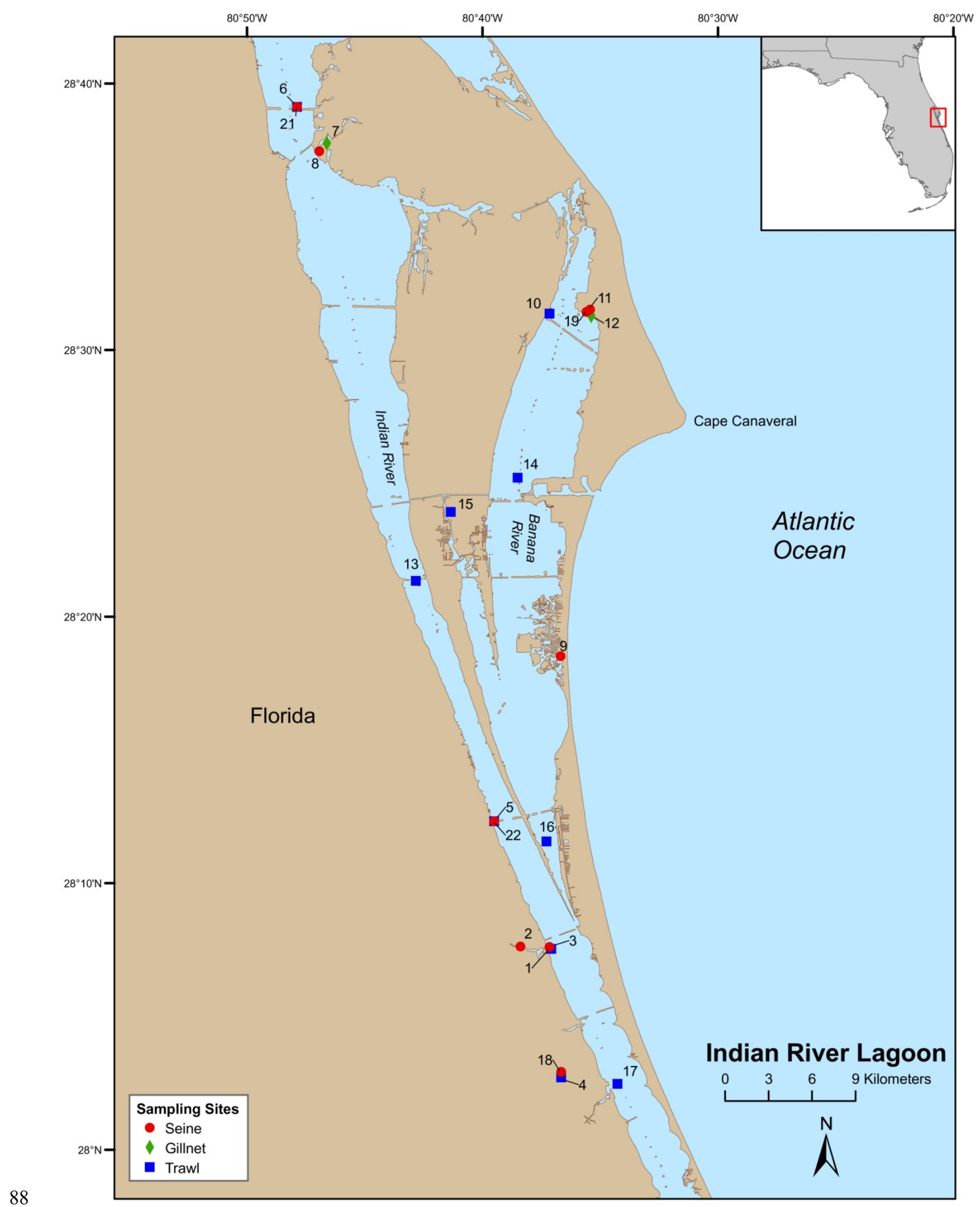

Figure 1. Map of Indian River Lagoon sampling stations. 


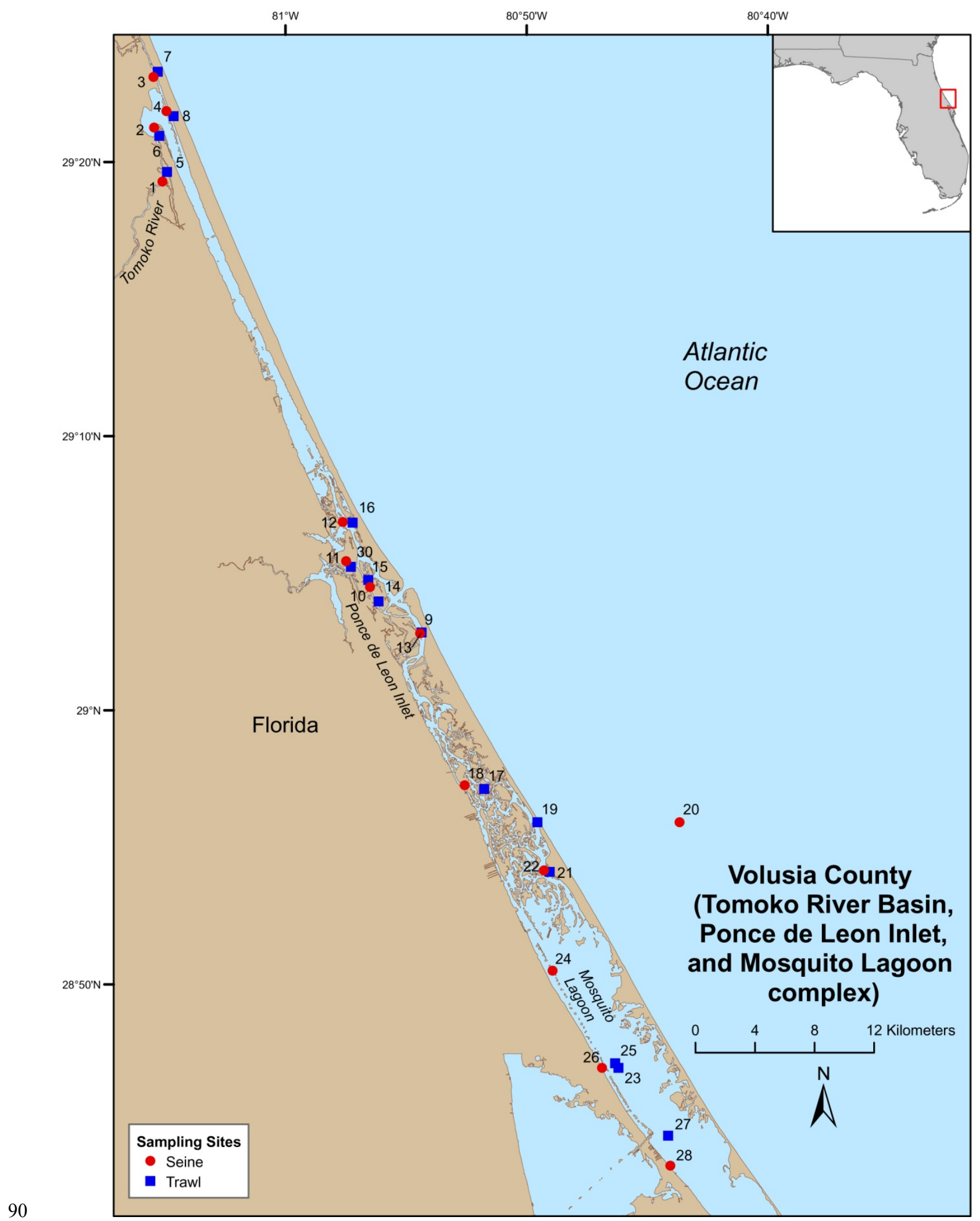

Figure 2. Map of Volusia County sampling stations. 
92

\section{Gear and Sampling Methodology}

Field sampling at FS was conducted once a month during daylight (i.e., the period between one hour after sunrise and one hour before sunset). Three haul repetitions were made at each station with a center-bag seine $(21.3 \mathrm{~m}$ long by $1.8 \mathrm{~m}$ high; center bag constructed of $3.2 \mathrm{~mm} \# 35$ knotless nylon Delta mesh). Based on the profile of the beach (i.e., bank slope) and water depth, one of three deployment methods (beach, boat, or offshore) were used to deploy the center-bag seine (i.e., seine) at each station (McMichael et al., 1995). The first deployment technique was the beach method. A beach deployment method was used when the water depth was shallow and the bank had either a gradual slope or no slope. The beach deployment method consisted of the seine being pulled parallel to shore by two biologists for a total distance of $9.1 \mathrm{~m}$; a $15.5 \mathrm{~m}$ line stretched between each seine pole was used to assure the net was being pulled the same innerpole distance for every haul. The second deployment technique was the boat deployment method. A boat deployment method was used when the water was either to deep (water depth $0.7-1.2 \mathrm{~m}$ ) or the bank was too steep to use a beach deployment. The boat deployment method consisted of deploying the seine from the stern in a semi-circular pattern along the bank. Once the seine was fully deployed, two biologists would pull the seine toward shore. The third and final deployment method was the offshore deployment method. An offshore deployment was used when there was either no available beach or it was too shallow to reach the beach bank by boat. The offshore deployment followed the same procedures as the beach deployment with one minor difference; at the end of the $9.1 \mathrm{~m}$ distance, two biologists worked the seine using a stationary pivot pole to ensure the catch did not escape (McMichael et al., 1995). Given the seine dimensions and the distance traveled $(9.1 \mathrm{~m})$ along the beach, the total area sampled with the beach seine was $100 \mathrm{~m}^{2}$. 
115 Data

116 The FWC used two experimental field sampling approaches in the 1990s to survey fish

117 throughout Florida (McMichael et al., 1995): monthly FS and year-round stratified random

118 sampling (SRS). The FWC conducted fisheries monitoring using a variety of sampling gears,

119 such as center-bag seines, otter trawls, gillnets, blocknets, and dropnets. For these analyses, data

120 was restricted to monthly FS collections of ladyfish collected with a center-bag seine because

121 fewer juvenile ladyfish were collected with the SRS approach. Therefore, pooling the datasets

122 (SRS and FS) could have bias the analyses by under- or over-estimating size-at-age. Also, most

123 ladyfish collected by the SRS approach were larger and older than the pre-selected maximum

124 cut-off length of $100 \mathrm{~mm}$ SL. Following Levesque (2014), a maximum cut-off length of $100 \mathrm{~mm}$

125 SL was chosen because ladyfish larger than $100 \mathrm{~mm}$ SL could avoid some field sampling gear

126 (i.e., small-mesh center-bag seines). After every net haul, fish were sorted, enumerated, and

127 measured to the nearest $1 \mathrm{~mm}$ standard length (SL); a total of 20 individuals of every species

128 were measured. It should be noted these data were collected prior to McBride et al. (2010)

129 describing Elops smithi; Elops saurus and Elops smithi are both found on the east coast of

130 Florida. Unfortunately, the FWC team was unaware at the time of the study that there were

131 potentially two different species of ladyfish that could be found within the study area. As such,

132 my findings only refer to the genus Elops.

133 Statistical analysis

134 Data were evaluated for normality and homoscedacity (variance [equivalently standard

135 deviation] are equal) using Kolmogorov-Smirnov (Zar, 1999) and Bartlett (Bartlett, 1937a;

136 1937b) tests, respectively. If the data passed the normality tests, then parametric procedures were

137 followed; otherwise, the data were $\log$-transformed $[\log (\mathrm{X}+1)]$ to meet the underlying 
assumptions of normality (Zar, 1999). Non-parametric procedures were applied if the data could not meet the assumptions of normality after transformation. A post-hoc multiple comparison test was used to perform pairwise comparisons in the presence of significance at the 95 percent confidence level for either the Analysis of Variance (ANOVA) or Kruskal-Wallis nonparametric multi-sample tests. All analyses were conducted using Microsoft Excel ${ }^{\circledR}$ and Statgraphics Centurion $\mathrm{XVI}^{\circledR}$ Version 16.1. Statistical significance was defined as $P<0.05$. To estimate growth, monthly field collections of cohort lengths were categorized into 5 mm SL size classes, graphed, and evaluated. Descriptive statistics (e.g., mean, standard deviation, variance, standard error) were derived and cohorts identified using modal progression analysis (MPA); MPA consisted of plotting the mean SL and the collection date (Petersen, 1892). Before evaluating cohort modal progressions, a one-way ANOVA test was used to distinguish whether there was a significant difference in length among months, years and locations. Annual ladyfish growth was estimated by regression analyses of the monthly geometric mean SL on capture date. Growth was described by linear (SL = slope [age] + yintercept) and nonlinear regression. The coefficient of determination value was used to choose the most parsimonious (i.e., the model that best fit the data) growth model. Exponential growth regression was described with the following equation:

Where,

$\mathrm{SL}=$ standard length $(\mathrm{mm}) ; \mathrm{G}=$ instantaneous growth coefficient (per month); $\mathrm{L}_{\mathrm{o}}=$ initial $\mathrm{SL}$ (mm) size at first capture; $\mathrm{t}=$ the time (per month) for the average individual in the length-class to achieve the indicated size. 
161 The relative instantaneous growth coefficient $(\mathrm{G})$ was estimated by calculating the average time 162 individuals in a year-class attained a certain length (Deegan, 1990). The instantaneous growth coefficient was used to represent the average growth of the population during the time period (Ricker, 1975). The absolute daily growth rate was estimated by the following equation:

$$
\mathrm{G}=\Delta \mathrm{l}\left(\mathrm{l}_{2}-\mathrm{l}_{1}\right) / \Delta \mathrm{t}\left(\mathrm{t}_{2}-\mathrm{t}_{1}\right)
$$

Where, $1_{2}=\mathrm{SL}(\mathrm{mm})$ at the end of a unit of time; $1_{1}=$ initial SL $(\mathrm{mm})$ at time $0 ; \mathrm{t}_{2}=$ at the end of a unit of time (days); $\mathrm{t}_{1}=$ initial time 0 (days).

Analysis of Covariance (ANCOVA) was used to determine if the slopes of the regression lines were significantly different (homogeneity of slopes assumption); significance criteria (homogeneity of y-intercepts and coincidental slopes and intercepts of the regression lines) was achieved when the parallelism of slopes assumption was met. If annual growth rates were equal, then the data were pooled. Following Ricker (1975), it was assumed: (1) the population sampled had a normal distribution; (2) the size classes (captured) were not influenced by gear or sampling methods; (3) mortality was the only natural population influence; and (4) the population was resident to the sampling location (i.e., lack of immigration or emigration). In general, I assumed a steady- state and a closed-population. These basic assumptions are often applied to derive various life-history estimates, including mortality and recruitment (Ziegler et al. 2011). Based on Levesque (2014) and McBride et al. (2001), these population assumptions seemed reasonable because the data was limited to seine gear, and most of the sampling stations were located in ideal ladyfish habitat (Eldred and Lyons, 1966; Gilmore et al. 1981; McBride et al. 2001; FWRI, 
185 186

2006).

Growth and growth rates were evaluated to ensure estimates were realistic and

biologically accurate given ladyfish have a metamorphic development (i.e., leptocephalus). Since ladyfish early development consists of the body shrinking before it transitions into the juvenile stage, estimating growth is somewhat challenging compared to most fish, especially if attempting to back-calculate size and age. If the derived size was unrealistic both in terms of recruitment and projected age-1 length, then size was corrected (y-intercept) to compensate for the unrealistic smaller predicted recruitment size and larger projected age-1 length. Using linear regression, the y-intercept of the exponential regression formula was corrected (standardized) to $21 \mathrm{~mm}$ SL to better reflect natural growth. The $21 \mathrm{~mm}$ SL was selected because it is generally the length ladyfish have before transitioning from the leptocephalus to the juvenile stage (Alikunhi and Rao, 1951; Gehringer, 1959). It is also the minimum size usually collected with a $3.2 \mathrm{~mm} \# 35$ knotless Delta mesh beach seine. It should be noted that this mesh size seine can potentially capture smaller individuals, but $20 \mathrm{~mm} \mathrm{SL}$ is a conservative size.

\section{RESULTS}

Length-frequency

A total of 767 juvenile ladyfish ranging from 1 to $99 \mathrm{~mm} \mathrm{SL} \mathrm{(} \bar{x}=48.8 \mathrm{~mm}, \mathrm{~S} . \mathrm{D} . \pm 26.3 \mathrm{~mm})$ were collected in the IRL during 1991 through 1995. Annual monthly length-frequency distributions were confounded because a few small individuals were collected throughout the year; monthly length-frequency data generally demonstrated a cyclical pattern (Fig. 3, 4). The smallest ladyfish $(\bar{x}=12.5 \mathrm{~mm} \mathrm{SL}$, S.D. $\pm 13.4 \mathrm{~mm}, n=2)$ were collected in September and the largest $(\bar{x}=65.3 \mathrm{~mm} \mathrm{SL}$, S.D. $\pm 28.2 \mathrm{~mm}, n=174)$ in May $[F(11,753)=31.87, P<0.001]$. 
Post-hoc analysis showed no significant difference in length between August and May, or among

209 the other months. Two separate one-way ANOVAs showed length during April $[F(2,97)=0.15$,

$210 P=0.86]$ and June $[F(3,50)=2.35, P<0.08]$ was not significantly different among years;

211 however, mean length in May was significantly different among sampling years $[F(2,187)=$

212 21.44, $P<0.001]$. The smallest ladyfish $(\bar{x}=42.7 \mathrm{~mm} \mathrm{SL}$, S.D. $\pm 16.73 \mathrm{~mm}, n=44)$ captured in

213 May occurred in 1993 and the largest ( $\bar{x}=64.6 \mathrm{~mm} \mathrm{SL}$, S.D. $\pm 14.01 \mathrm{~mm}, n=98)$ in 1995.

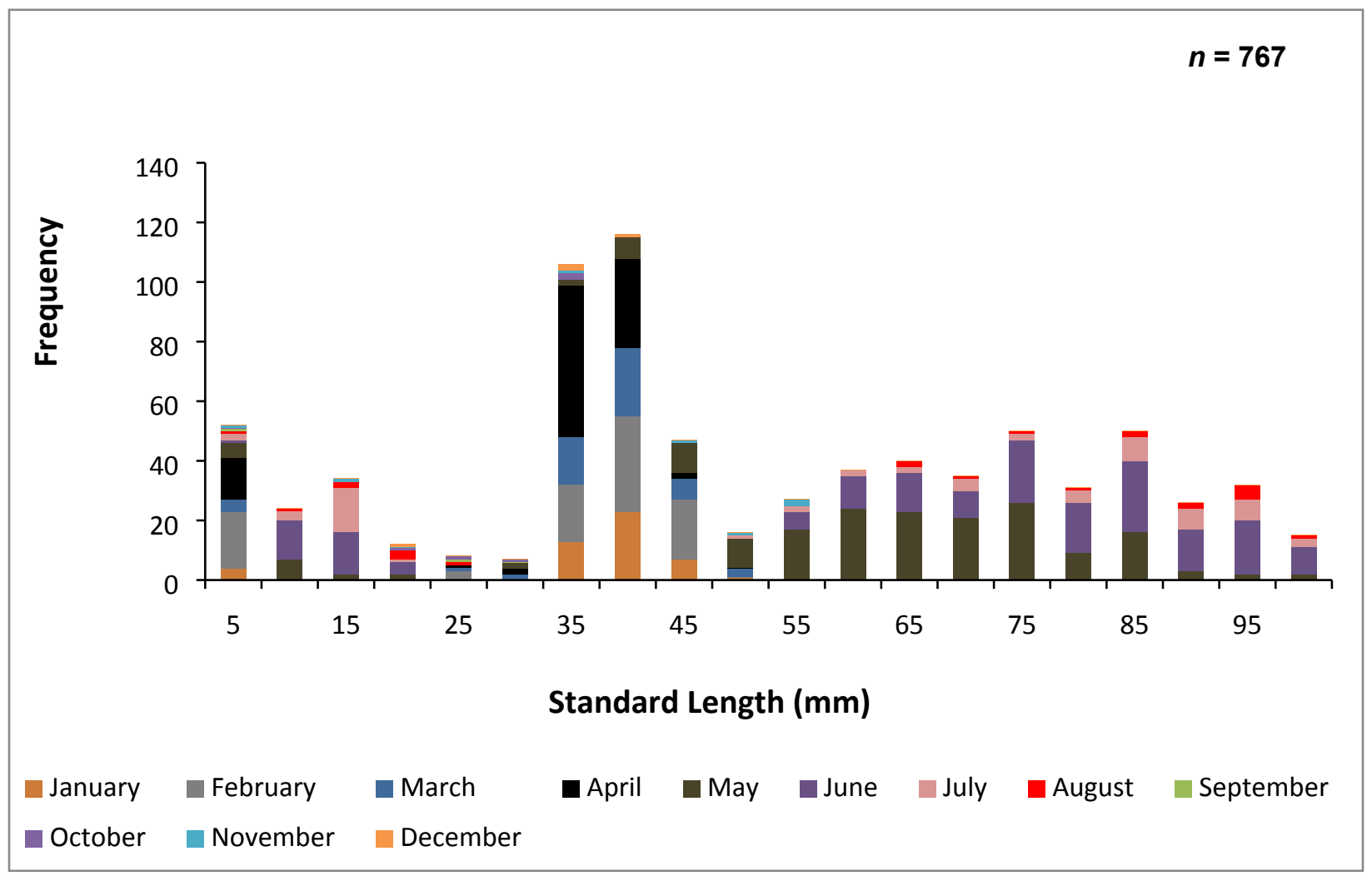

Figure 3. Number of ladyfish collected by standard length (mm) in the Indian River 
$n=767$

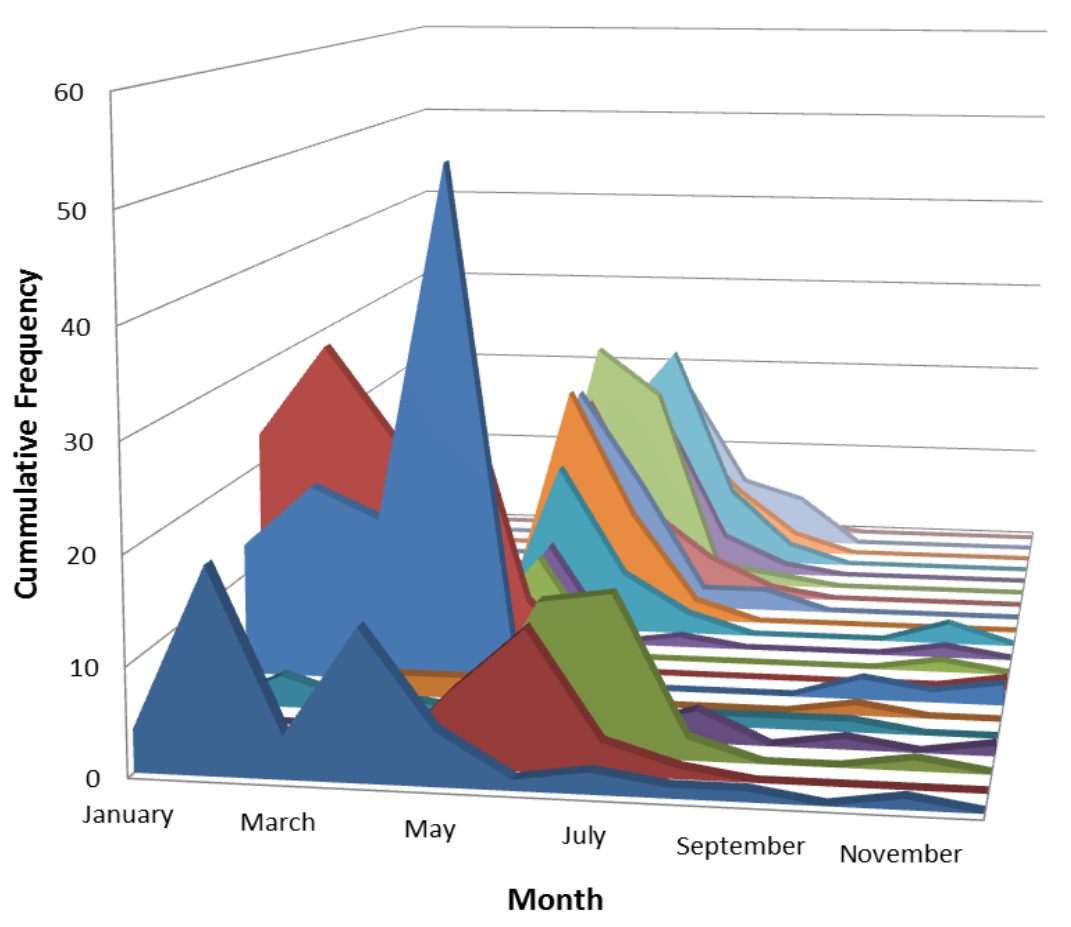

\section{Figure 4. Number and size of ladyfish collected by month in the Indian River Lagoon, Florida during 1991 through 1995.}

One hundred and sixty-nine juvenile ladyfish ranging from 2 to $99 \mathrm{~mm}$ SL ( $\bar{x}=34.3 \mathrm{~mm}$ SL, S.D. $\pm 16.92 \mathrm{~mm}$ ) were collected in VC waters during 1993 through 1995 . Annual monthly length-frequency distribution demonstrated that growth generally occurred from late-winter and spring to summer (Fig. 5, 6). The smallest ladyfish ( $\bar{x}=19.3 \mathrm{~mm} \mathrm{SL}$, S.D. $\pm 19.61 \mathrm{~mm}, n=4)$ were collected in February and the largest ( $\bar{x}=70.8 \mathrm{~mm} \mathrm{SL}$, S.D. $\pm 34.24 \mathrm{~mm}, n=4)$ in August $[F(8,160)=6.04, P<0.001]$. Post-hoc analysis showed no significant difference in length among September, October, March, January, April, May, June, and August. In addition, no significant difference in length was found among February, September, October, March, January, April, and May. Three separate one-way ANOVAs showed length in April $[F(2,114)=0.65, P$ $=0.52]$, May $[F(2,4)=2.27, P=0.22]$, and June $[F(2,10)=1.88, P=0.20]$ was not significantly different among years. 
Figure 6. Number and size of ladyfish collected by month in Volusia County, Florida during 1993 through 1995.

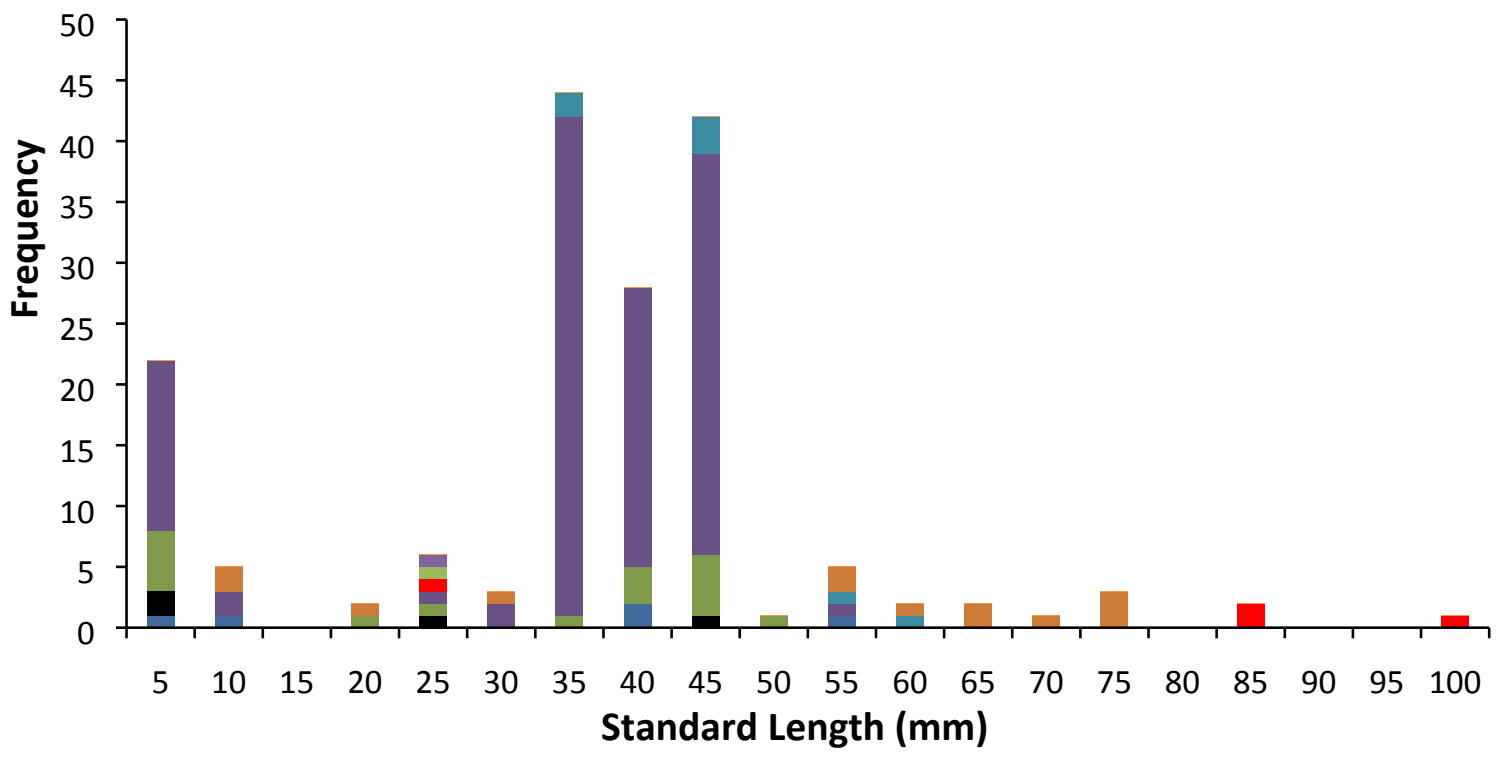

- January $\square$ February $\quad$ March April $\square$ May $\square$ June $\square$ July $\square$ August $\quad$ September - October November December

Figure 5. Number of ladyfish collected by standard length $(\mathrm{mm})$ in Volusia County, Florida during 1993 through 1995.

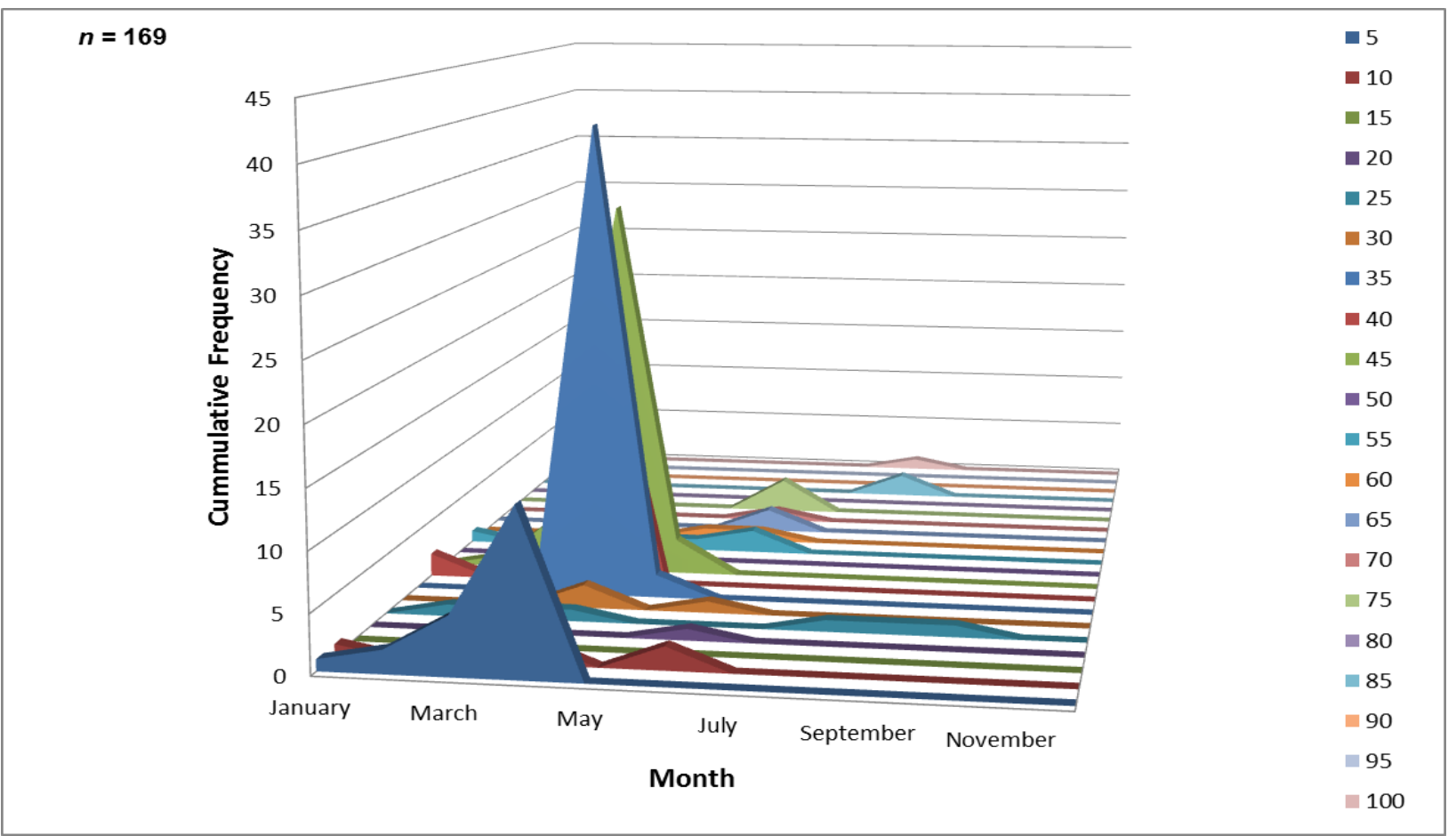


243

244

245

246

247

248

249

250

251

252

\section{Length-frequency progressions}

Ladyfish growth in the IRL was unable to be estimated by the progression of monthly cohort sizes as recruitment of smaller individuals occurred throughout the year. Therefore, for comparison purposes, and to eliminate recruitment bias (i.e., influx of small individuals), growth evaluations in the IRL were limited to catches occurring from April to June. This corresponded to the period when recruitment was not only consistent, but monthly mean size generally increased from one month to the next. The monthly instantaneous growth coefficient ranged from -0.0677 in 1995 to 0.094 in 1991. Absolute growth ranged from 0.55 in 1992 to $0.63 \mathrm{~mm}$ day $^{-1}$ in 1993 and 1994. On average, the absolute growth rate was $36.3 \mathrm{~mm}$ in 60 days or 0.605 $\mathrm{mm}$ day $^{-1}$. Cohort-specific daily growth rates, elevations, and coincidentals (slopes and intercepts of the regression lines) were similar among sampling years $[F(1,2)=0.0035, P=0.3146] ;[F$ $(1,3)=1.545, P=0.2702] ;[F(2,2)=0.5177, P=0.3121]$, respectively. Cohort-specific growth rates ranged from 1.807 in 1993 to $1.811 \mathrm{~mm}^{-1}$ day $^{-1}$ in $1994\left(\bar{x}=1.811 \mathrm{~mm}^{-1 a y}\right.$, S.D. \pm 0.003 mm day ${ }^{-1}$ ). The overall growth was best (i.e., goodness of fit) described by an exponential regression having the formula: $\mathrm{SL}=9.5030^{0.3226(\mathrm{age})} ; \mathrm{r}^{2}=0.8474$ (Fig. 7, 9). If the exponential trajectory rate was maintained over 365 days, ladyfish would attain a standard length of 457.5 $\mathrm{mm}$ corresponding to an estimated growth rate of $1.25 \mathrm{~mm}_{\text {day }}^{-1}$ (Tables $\mathbf{1 , 2}$ ). The corrected exponential growth equation yielded a size-at-age 1 of $156.0 \mathrm{~mm} \mathrm{SL}$, which corresponded to an estimated growth rate of $0.4356 \mathrm{~mm} \mathrm{day}^{-1}$ (Tables 1, 2). 


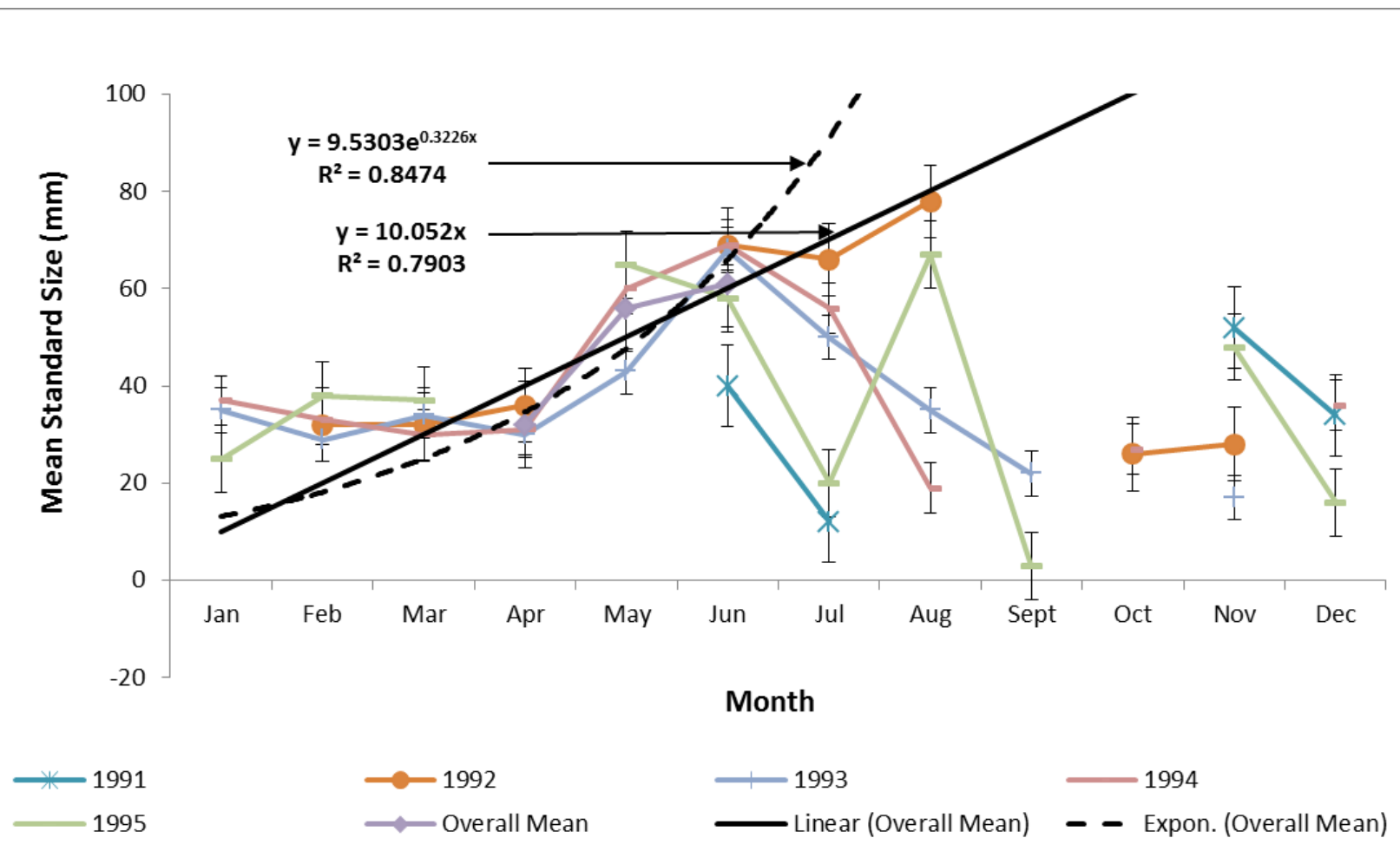

Figure 7. Annual mean growth of juvenile ladyfish collected in the Indian River Lagoon, Florida during 1991 through 1995.

Estimating ladyfish growth from VC collections was also problematic because

recruitment of small individuals occurred throughout the year and the estimated growth rate varied among sampling years. Therefore, to compensate for the recruitment of small individuals in $\mathrm{VC}$, growth evaluations were limited to catches occurring from March to August. The monthly instantaneous growth coefficient ranged from - 0.3061 in 1995 to 0.3324 in 1994. Absolute growth ranged from 0.3833 in 1993 to $0.5833 \mathrm{~mm} \mathrm{day}^{-1}$ in 1994. On average, the absolute growth rate was $28 \mathrm{~mm}$ in 150 days or $0.1866 \mathrm{~mm}^{\text {day }}{ }^{-1}$. Cohort-specific daily growth rates were significantly different among sampling years $[F(2,15)=3.6921, P=0.0497]$; however, the elevations and coincidentals were similar $[F(2,17)=0.4349, P=0.3927] ;[F(4,15)=2.1324$, $P=0.1402]$, respectively. Cohort-specific growth rates ranged from 1.741 in 1994 to $1.933 \mathrm{~mm}$ day $^{-1}$ in 1993 ( $\bar{x}=1.837 \mathrm{~mm} \mathrm{day}^{-1}$, S.D. \pm 0.14$)$. Mean ladyfish growth was best (i.e., goodness 
277 of fit) described by a linear regression having the formula: $\mathrm{SL}=5.4429$ (age [days]) $+11.1 ; \mathrm{r}^{2}=$

278 0.8711. However, natural growth was explained better by the exponential regression formula:

$279 \mathrm{SL}=16.846^{0.1545(\mathrm{age})} ; \mathrm{r}^{2}=0.8659($ Fig. 8, 9). If the exponential trajectory rate was maintained

280 over 365 days, ladyfish would attain a standard length of $107.6 \mathrm{~mm}$ corresponding to an

281 estimated growth rate of $0.2951 \mathrm{~mm} \mathrm{day}^{-1}$ (Tables 1, 2). The corrected exponential growth

282 equation yielded a size-at-age 1 of $80 \mathrm{~mm} \mathrm{SL}$ corresponding to an estimated growth rate of

$2830.2361 \mathrm{~mm} \mathrm{day}^{-1}$ (Tables 1, 2).

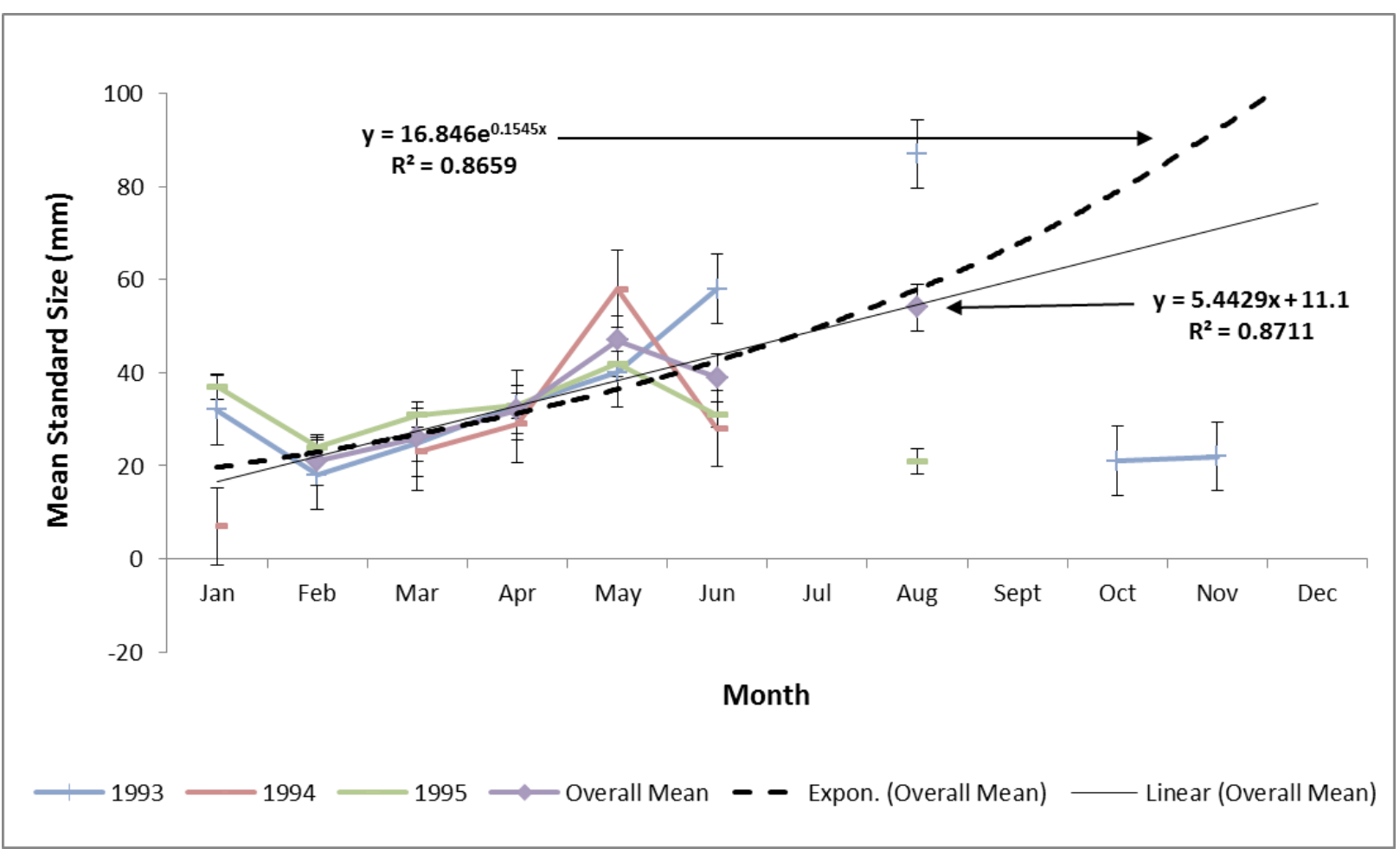

\section{Figure 8. Annual mean growth of juvenile ladyfish collected in Volusia County, Florida during 1993 through 1995.}


Figure 9. Overall mean growth of juvenile ladyfish collected in the Indian River Lagoon

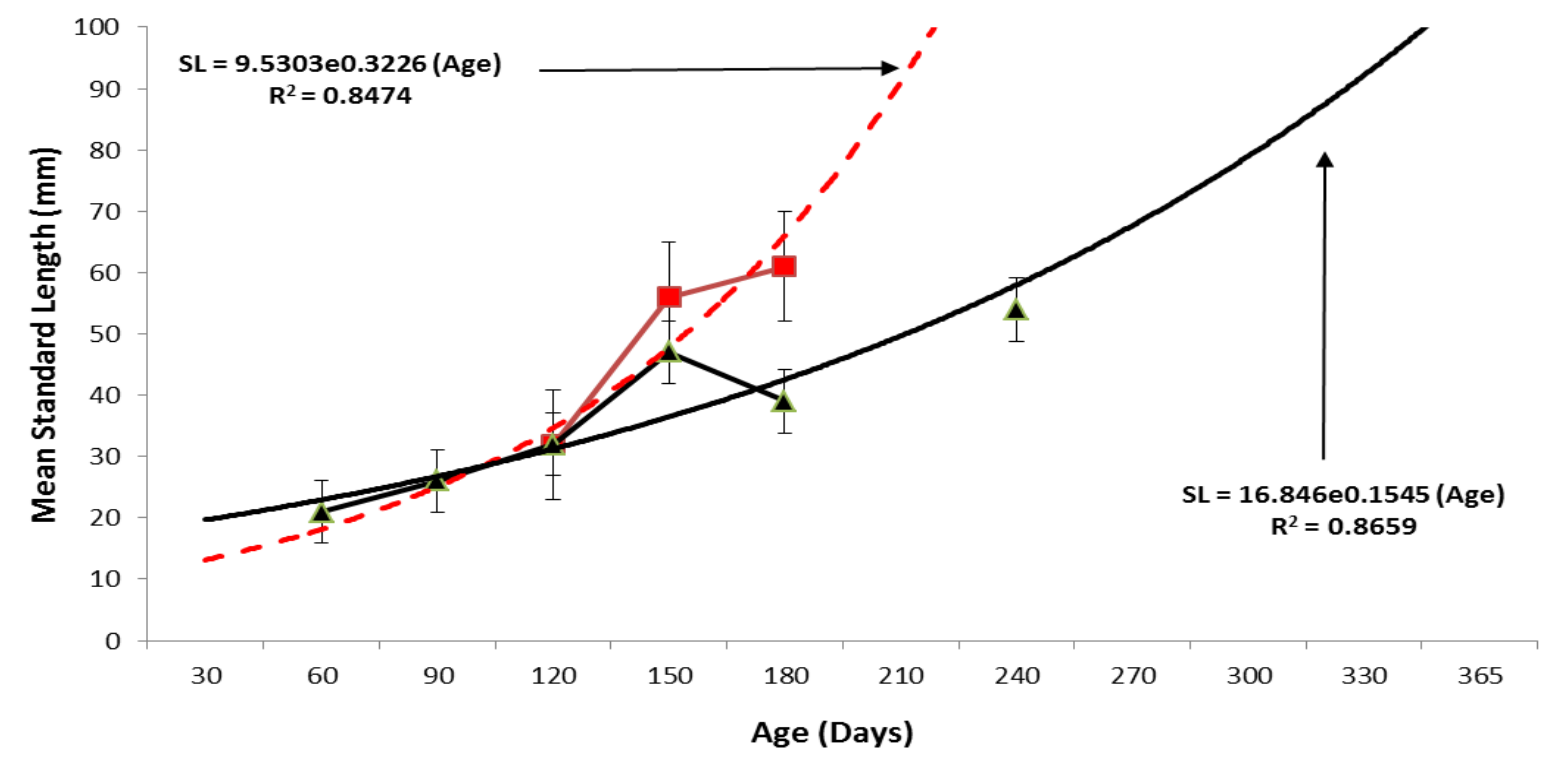

$\longrightarrow$ - Indian River Lagoon $\longrightarrow$ - Volusia County $\quad-$ Expon. (Indian River Lagoon)

Expon. (Volusia County) and Volusia County, Florida during 1991 through 1995. 
Table 1. Corrected and non-corrected juvenile ladyfish growth rates and size-at-age 1 (without compensating for time required for leptocephalus to metamorphosis from egg to juvenile) based on length-frequency analysis by location. The annual mean growth rate and size-at-age 1 was estimated by pooling the data for each location. The y-intercept of the exponential regression formula was corrected to $21 \mathrm{~mm}$ SL to better reflect natural growth (shaded cells). Locations are as follows: Indian River Lagoon (IRL), Tampa Bay (TB), Volusia County (VC [Tomoko River Basin, Ponce de Leon Inlet, and Mosquito Lagoon complex]), and Little Manatee River (LMR). Data for TB and LMR was reported by Levesque (2014).

\begin{tabular}{|c|c|c|c|c|c|c|c|c|}
\hline \multirow[t]{2}{*}{ Year } & \multicolumn{4}{|c|}{ Growth Rate (mm/day) } & \multicolumn{4}{|c|}{ Size-at-Age 1 (mm SL) } \\
\hline & TB & IRL & $\mathrm{VC}$ & LMR & TB & IRL & $\mathrm{VC}$ & LMR \\
\hline \multirow[t]{2}{*}{1988} & - & - & - & 0.0001 & - & - & - & 0.0449 \\
\hline & & & & 0.0259 & & & & 9.5 \\
\hline \multirow[t]{2}{*}{1989} & 1.76 & - & - & 3.976 & 643.2 & - & - & 1451.5 \\
\hline & 0.9175 & & & 0.5658 & 334.9 & & & 206.5 \\
\hline \multirow[t]{2}{*}{1990} & 1.41 & - & - & 0.0382 & 515.2 & - & - & 13.9 \\
\hline & 0.5671 & & & 0.1284 & 207.0 & & & 46.9 \\
\hline \multirow[t]{2}{*}{1991} & 0.98 & 0.1102 & - & - & 358.2 & 40.2 & - & - \\
\hline & 0.4123 & 0.0986 & & & 150.5 & 35.9 & & \\
\hline \multirow[t]{2}{*}{1992} & 0.58 & 0.1173 & - & - & 211.5 & 42.8 & - & - \\
\hline & 0.4452 & 0.1172 & & & 162.5 & 42.8 & & \\
\hline \multirow[t]{2}{*}{1993} & 11.78 & 0.0711 & 0.0980 & - & 4301.3 & 25.9 & 35.8 & - \\
\hline & 0.4378 & 0.1132 & 0.1224 & & 159.8 & 41.3 & 44.7 & \\
\hline \multirow[t]{2}{*}{1994} & 2.74 & 0.1074 & 0.9934 & - & 1001.1 & 39.2 & 362.8 & - \\
\hline & 0.6693 & 0.1339 & 0.1568 & & 244.3 & 48.8 & 57.3 & \\
\hline \multirow[t]{2}{*}{1995} & 1.20 & 0.0542 & 0.0630 & - & 436.8 & 19.8 & 23.0 & - \\
\hline & 0.5304 & 0.0754 & 0.1224 & & 193.6 & 27.5 & 44.7 & \\
\hline
\end{tabular}


Table 2. Juvenile ladyfish growth rates and size-at-age 1 based on length-frequency analysis in Florida waters by location. For comparison purposes, the direct method growth rate determined by captive rearing (Levesque, 2014) is shown along with available ladyfish age and growth estimates from previous studies (Alikunhi \& Rao, 1951; Gehringer, 1959; McBride et al., 2001). The overall mean growth rate and size-at-age 1 was estimated by pooling the data for each location. The y-intercept of the exponential regression formula was corrected to $21 \mathrm{~mm}$ SL to better reflect natural growth (shaded cells). Locations are as follows: Indian River Lagoon (IRL), Tampa Bay (TB), Volusia County (VC [Tomoko River Basin, Ponce de Leon Inlet, and Mosquito Lagoon complex]), and Little Manatee River (LMR). Data for TB and LMR was reported by Levesque (2014).

\begin{tabular}{|c|c|c|c|c|c|c|c|c|}
\hline \multirow[t]{2}{*}{ Age Determination Method } & \multicolumn{4}{|c|}{ Growth Rate (mm/day) } & \multicolumn{4}{|c|}{ Size-at-age 1 (mm SL } \\
\hline & TB & IRL & $\mathrm{VC}$ & LMR & TB & IRL & $\mathrm{VC}$ & LMR \\
\hline Present Study: Length- & 1.11 & 1.25 & 0.2947 & 1.04 & 403.6 & 457.5 & 107.6 & 380.9 \\
\hline $\begin{array}{l}\text { Frequency Analysis } \\
\text { (data pooled) }\end{array}$ & 0.9101 & 0.4356 & 0.2356 & 0.3882 & 332.2 & 156.0 & 80.0 & 141.7 \\
\hline
\end{tabular}

Levesque (2014)

Alikunhi \& Rao (1951)

Gehringer (1959)

0.8134

296.9

McBride et al., (2001) 


\section{DISCUSSION}

Laslett et al. (2004) indicated the progression of cohort growth can be modeled under certain circumstances, but using length-frequency data to estimate fish growth is not always a straightforward approach. Realistic age and growth estimates for juvenile ladyfish using lengthfrequency data were derived, but I did have to consider monthly and annual recruitment patterns in my analyses. Therefore, the interpretation and discussion of these results are reported with some reservation since the length-frequency data were rather unpredictable and ages were not directly validated with hard body parts (i.e., otoliths). Findings showed that the recruitment phase was inconsistent and prolonged from year-to-year in the IRL and VC waters, which made predicting growth more difficult since data could not be pooled. Overall, monthly recruitment varied somewhat due to the immigration of a few individuals. It is difficult to explain whether these individuals were either Elops saurus or Elops smithi since both species are found on the east coast of Florida. Also, understanding the results was challenging because these data were collected prior to McBride et al. (2010) described the new species; unfortunately, field staff were unaware of the two Elops species potentially occurring at the same time in the study area. Available information suggest that $E$. smithi have an extended recruitment period and it could be year round (McBride \& Horodysky, 2010; McBride et al., 2010), which might explain the inconsistent pattern in recruitment. Laslett et al. (2004) also stated that variability in annual growth needs to be considered during length-frequency analyses since environmental conditions might be more favorable for growth in some years, especially between and among species. Although information describing growth for E. smithi is unavailable, it is possible that environmental conditions (i.e., temperature) may influence the two Elops species differently. Interestingly, the data showed that mean ladyfish size, during some months of the recruitment 
343 phase, varied among sampling years in the IRL, but not in VC. Nonetheless, regression analysis

344 showed there was no significant difference in ladyfish growth among sampling years in the IRL.

McBride et al. (2001) reported ladyfish in the IRL attain between 250 and $270 \mathrm{~mm}$ SL by age-1. However, my findings showed that the growth rate and projected age-1 length was significantly smaller (156.0 mm SL [IRL] and $107.6 \mathrm{~mm} \mathrm{SL} \mathrm{[VC])} \mathrm{than} \mathrm{their} \mathrm{estimates.}$ Strangely, I derived different age-1 estimates for the IRL and VC despite the close proximity between the two areas. It is highly probable that the difference in age-1 length was related to differences in recruitment of E. saurus and E. smithi. However, another possible explanation for the difference in predicted age-1 length could have been attributed to either differences in environmental factors (e.g., water temperature, $\mathrm{pH}$, salinity, and dissolved oxygen) or habitat between the two areas. It is probably unlikely that environmental factors were significantly different between the areas given their geographic similarity and close proximity, so it is possible that there were slight differences in suitable habitat or prey availability; fish grow differently depending on the habitat (Sogard, 1992; Phelan et al. 2000). Again, as stated above, these data were collected before $E$. smithi was described by researchers so there is no way to thoroughly explain why I found differences in predicted age-1 size between the IRL and VC.

Regardless of the reasons why the data displayed some variability in annual monthly size, growth was reasonably modeled using length-frequency data; this confirms the applicability of length-frequency data for estimating annual growth. Though the projected age-1 length for VC (108 mm SL) was possibly misleading given the small sample size, the overall projected age-1 length (108-458 mm SL) seemed reasonable. In TB (Levesque, 2014) and the IRL (this present study), the projected lengths at age-1 were 404 and $458 \mathrm{~mm} \mathrm{SL}$, respectively. However, when growth rates were corrected (y-intercept) to compensate for the unrealistic smaller predicted 
recruitment size and larger projected age-1 length, age-1 length were $332 \mathrm{~mm}$ SL for TB and 159 $\mathrm{mm}$ SL for the IRL. I would like to point out that the predicted age-1 length in TB was 52\% longer than the length predicted for the IRL, so it is probable that corrected (y-intercept) length $(21 \mathrm{~mm})$ was overestimated. If the corrected size was adjusted to a lower value (15.5 $\mathrm{mm} \mathrm{SL})$, then the projected age-1 length would be $239 \mathrm{~mm}$ SL, which is still a smaller (28\%) age-1 size than predicted by Levesque (2014) for TB. Thus, it appears ladyfish from the east coast of Florida are either smaller at age-1 than on the west coast (i.e., TB) or the projected growth regression formula was inaccurate or misleading. Based on field-collections, it is more probable that the corrected growth rate was accurate since the projected recruitment size (y-intercept) value of $15.5 \mathrm{~mm}$ SL was within the size range of individuals collected during the peak recruitment phase. It is difficult to speculate why there was a difference in predicted age-1 size between the two east coast areas, but it is likely that it was related to sample size or the presence of two Elops species. This present study derived a different estimated ladyfish age-1 size than McBride et al. (2001), which emphasizes how differences in data treatment can affect the outcome. For instance, this study evaluated ladyfish collected with a center-bag seine since the objective was to evaluate juvenile ladyfish sizes $(<100 \mathrm{~mm} \mathrm{SL})$ rather than all life-stages (McBride et al., 2001).

My length-frequency derived age-1 size estimates were similar to those reported by Levesque (2014) for captive reared ladyfish. Overall, length-frequency proved to be a satisfactory approach for estimating juvenile ladyfish age and growth from east coast waters of Florida. Few researchers have reported age and growth estimates for ladyfish, so it is difficult to compare these findings to others, but it appears that ladyfish (Elops sp) in the western North Atlantic Ocean (McBride et al., 2001; Levesque, 2014) grow faster than ladyfish (E. affinis and 
E. lacerta) in other regions (Blake \& Blake, 1981; Ugwumba, 1989).

CONCLUSIONS

392

393

Understanding a species' life-history characteristics is necessary for making informed decisions and implementing successful management measures. My findings offer insight into juvenile ladyfish growth, and demonstrate the usefulness of the Petersen method for estimating age and growth. These findings show that growth can be reasonably modeled through indirect methods (i.e., length-frequency progression), but results should be viewed with caution, particularly if there is variability in mean length during the recruitment period (within and among locations). Although it's not recommend that the Petersen approach be applied to species with an extended recruitment period, it is possible to derive reasonable growth estimates as long as appropriate analytical steps are followed. As evident in this study and others (McBride et al., 2001; Levesque, 2014), derived growth rates were sensitive to analyses, so it is recommended that researchers use long-term datasets when attempting to estimate growth from alternative methods. In general, researchers should consider evaluating at least a 2-4 year time-series to resolve interannual trends, but the time-series length depends on various biological and environmental factors (e.g., local variability, geographical location, sampling gear, habitat, species, size-class, and the number of replicates).

\section{ACKNOWLEDGEMENTS}

Special thanks are owed to the Fisheries Independent Monitoring (FIM) staff of the Florida Fish and Wildlife Research Institute; thank you for your dedicated field sampling, sorting, and gear maintenance efforts. I especially thank B. McMichael and T. McDonald for kindly providing 
412 access to the FIM data. Also, I thank C. DeCurtis and B. Reiser for providing editorial comments

413 and edits that greatly improved the quality of this manuscript. I also thank K. Knight and P.

414 Gehring for providing GIS graphics support. Lastly, I thank C. Hager and an anonymous

415 reviewer for their editorial and technical critique of the article.

416

417

418

419

420

421

422

423

424

425

426

427

428

429

430

431

432

433

434

435

436

437

438

439

440

441

442

443

444

445

446

447

448

449

450

451

\section{REFERENCES}

Adams AJ, Blewett DA. 2004. Spatial patterns of estuarine habitat use and temporal patterns in abundance of juvenile permit, Trachinotus falcatus in Charlotte Harbor, Florida. Gulf Caribbean Research 2: 129-139.

Alikunhi KH, Rao SN. 1951. Notes on the metamorphosis of Elops saurus Linn. and Megalops cyprinoides (Broussonet) with observations on their growth. Journal of Zoological Society of India 3: 99-109.

Bartlett MS. 1937a. Some examples of statistical methods of research in agriculture and applied biology. Journal of the Royal Society 4: 137-170.

Bartlett MS. 1937b. Properties of sufficiency and statistical tests. Proceedings of the Royal Society 160: 268-282.

Blake C, Blake BF. 1981. Age determination in six species of fish from a Mexican Pacific coastal lagoon. Journal of Fish Biology (18) 47: 1-478.

Brinda S, Bragadeeswaran S. 2005. Influence of physicchemical properties on the abundance of a few economically important juvenile fin-fishes of Vellar estuary. Journal of Environmental Biology 26: 109-112.

Cooke SJ, Philipp DP. 2004. Behavior and Mortality of Caught-and-Released Bonefish (Albula sp.) in Bahamas waters with implications for a sustainable recreational fishery. Biological Conservation 118: 549-607.

Cooke SJ, Danylchuk, AD, Danylchuk SA, Suski CD, Goldberg TL. 2009. Is catch-andrelease recreational fishing compatible with no-take marine protected areas? Ocean Coastal Management 49: 342-354.

Deegan LA. 1990. Effects of estuarine environmental conditions on population dynamics of young-of-the-year gulf menhaden. Marine Ecology Progressive Series 68: 195-205.

Eldred B, Lyons WG. 1966. Larval ladyfish, Elops saurus Linnaeus 1766, (Elopidae) in Florida and adjacent waters. Florida Board of Conservation Marine Laboratory Leaflet Service 
452

453

454

455

456

457

458

459

460

461

462

$$
\text { 4(2). } 6 \mathrm{p} \text {. }
$$

Fedler AJ, Hayes C. 2008. Economic Impact of Recreation al Fishing for Bonefish, Permit and Tarpon in Belize for 2007. p. 29.

FWRI. 2006. Ladyfish, Elops saurus. Florida Fish and Wildlife Conservation Commission, Fish and Wildlife Research Institute. $9 \mathrm{p}$

Gehringer JW. 1959. Early development and metamorphosis of the Ten-Pounder, Elops saurus Linnaeus. US Fish Wildlife Service Fish Bulletin 59: 619-647.

Gilmore RG, Jr., Donohoe CJ, Cooke DW, Herrema DJ. 1981. Fishes of the Indian River Lagoon and adjacent waters, Florida. Harbor Branch Foundation Technical Report 41. $36 \mathrm{p}$.

Greenwood PH, Rosen DE, Weitzman SH, Myers GS. 1966. Phyletic studies of teleostean fishes, with a provisional classification of living forms. Bulletin American Museum Natural History 131: 339-456.

Laslett GM, Eveson JP, Polacheck T. 2004. Fitting growth models to length frequency data. ICES Journal of Marine Science 61: 218-230.

Levesque JC. 2011. Is Today's Fisheries Research Driven by a Species Economic Value? A Case Study of Ladyfish (Elops saurus) Biology and Ecology. Reviews in Fishery Science (19) 2: 137-149.

Levesque JC. 2013. Spatial and Temporal Patterns in Abundance and Distribution of Juvenile Ladyfish (Elops saurus) in Florida Waters (USA). Fisheries and Aquaculture Journal 2013 volume: FAJ-76 1-23.

Levesque J.C. 2014. Age and growth of juvenile ladyfish (Elops sp) in Tampa Bay, Florida, USA. International Journal of Fisheries and Aquatic Studies (2) 2: 145-157.

McBride R, MacDonald T, Matheson R, Rydene D, Hood P. 2001. Nursery habitats for ladyfish, Elops saurus, along salinity gradients in two Florida estuaries. Fishery Bulletin 99: 443-458.

McBride RS, Horodysky AZ. 2004. Mechanisms maintaining sympatric distributions of two ladyfish (Elopidae: Elops) morphs in the Gulf of Mexico and western North Atlantic Ocean. Limnology and Oceanography (49) 4: 1173-1181.

McBride RS, Rocha CR, Ruiz-Carus R, Bowen BW. 2010. A new species of ladyfish, of the genus Elops (Elopiformes: Elopidae), from the western Atlantic Ocean. Zootaxa 2346: 29-41.

McMichael RH, Paperno R, McLaughlin BJ, Mitchell ME, 1995. Florida's marine fisheries- 
independent monitoring program: a long-term ecological dataset. Bulletin of Marine Science 57: 282-285.

Petersen C. 1892. Fiskenesbiologiske forhold i Holboek Fjord, 1890-1891. Beret. Landbugminist. Dan. Biol. Stn. (Fiskeriberet.) (1890) 1891: 121-84.

Phelan BA, Goldberg R, Bejda AJ, Pereira J, Hagan S, Clark P, Studholme AL, Calabrese A, Able KW. 2000. Estuarine and habitat-related differences in growth rates of young-of-the-year winter flounder (Pseudopleuronectes americanus) and tautog (Tautoga onitis) in three northeastern US estuaries. Journal of Experimental Marine Biology and Ecology 247: 1-28.

Ricker WE. 1975. Computation and interpretation of biological statistics of fish populations. Bull Fish Res Board Can 191: 382 p.

Sogard SM. 1992. Variability in growth rates of juvenile fishes in different estuarine habitats. Marine Ecology Progress Series 85: 35-53.

Smith D. 1989. Order Elopiformes, Families Elopidae, Megalopidae, and Albulidae: Leptocephali. Fishes of the Western North Atlantic. Memoir Sea. Found Mar Rsch 1: 961-972.

Ugwumba OA. 1989. Distribution and growth pattern of the tenpounder Elops lacerta (Val.) in the freshwater, estuarine and marine environments of Lagos, Nigeria. Arch. for Hydrobiology 15: 451-462.

Zale AV, Merrifield SG. 1989. Species profiles: Life histories and environmental requirements of coastal fishes and invertebrates (South Florida)--ladyfish and tarpon. U.S. Fish Wildlife Service Biological Report 82(11.104) U.S. Corps. of Engineers, TR EL-82-4. pp. 17.

Zar J. 1999. Biostatistical Analysis. Prentice-Hall, Englewood Cliffs. Upper Saddle River, New Jersey.

Ziegler PE, Welsford DC, Constable AJ. 2011. Length-based assessment revised-Why stock status and fishing mortality of long-lived species such as toothfish cannot be inferred from length-frequency data alone. CCAMLR Science 18: 57-73. 
1

Map of Indian River Lagoon sampling stations.

shows study area 


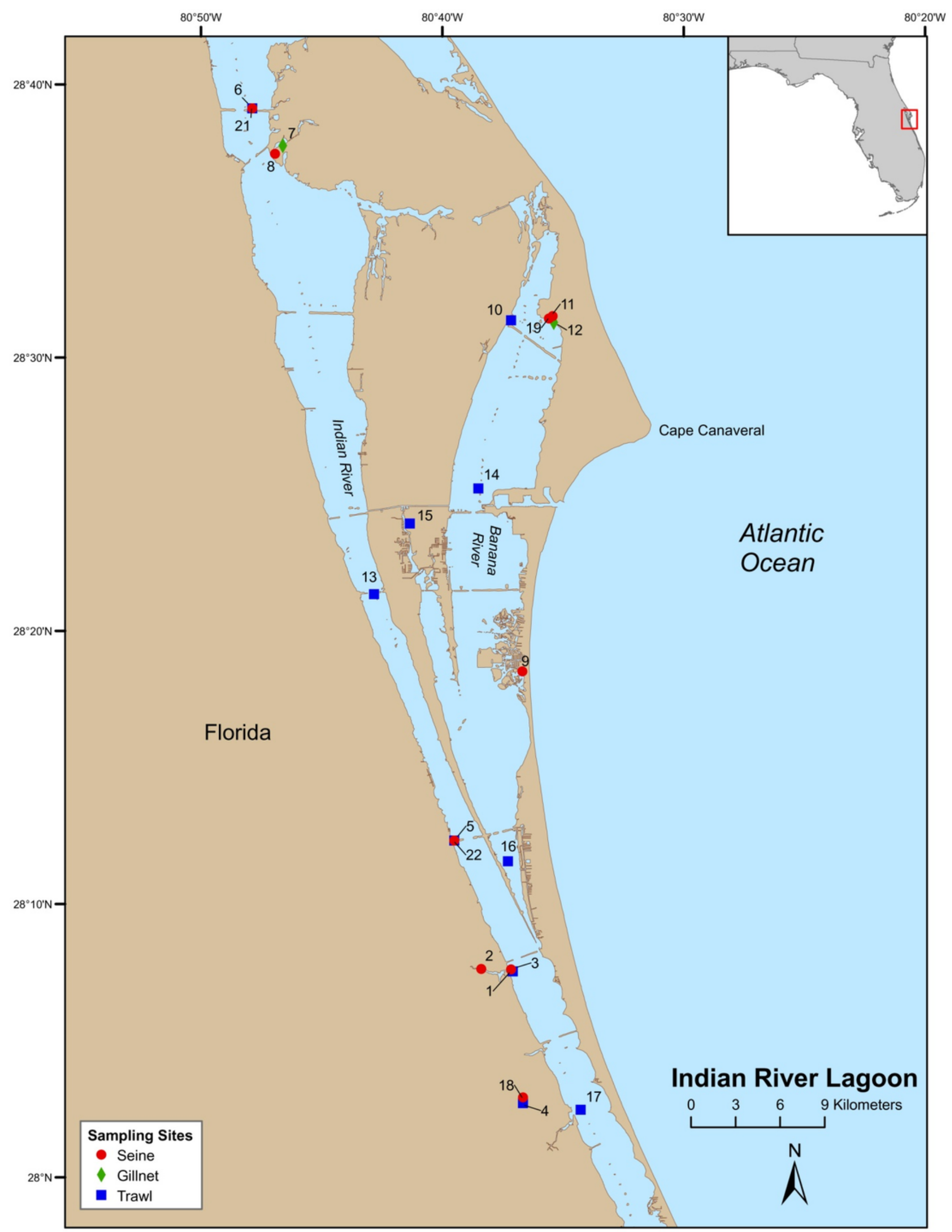


2

Map of Volusia County sampling stations. 


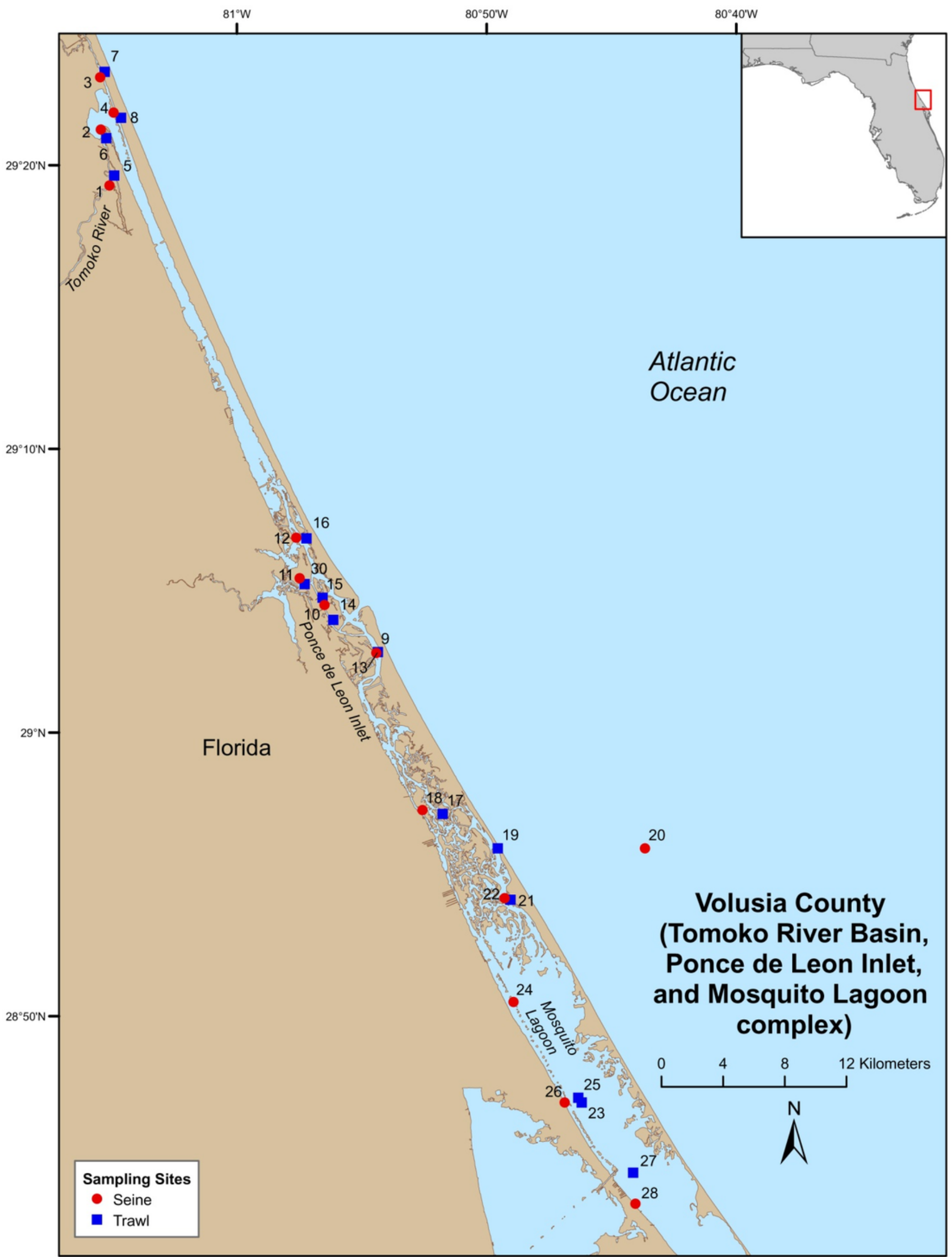


3

Number of ladyfish collected by standard length $(\mathrm{mm})$ in the Indian River Lagoon, Florida during 1991 through 1995.

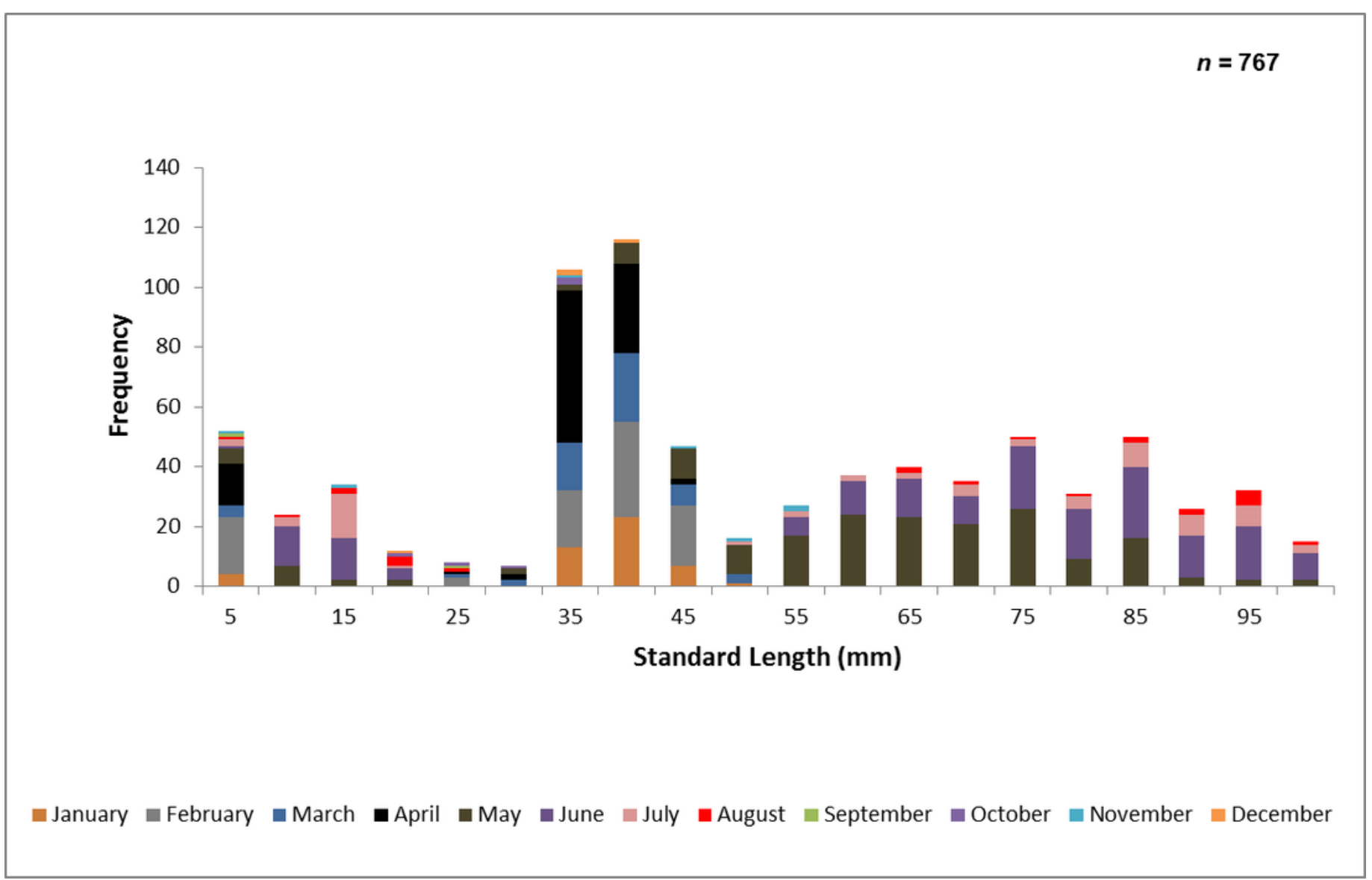


4

Number and size of ladyfish collected by month in the Indian River Lagoon, Florida during 1991 through 1995.

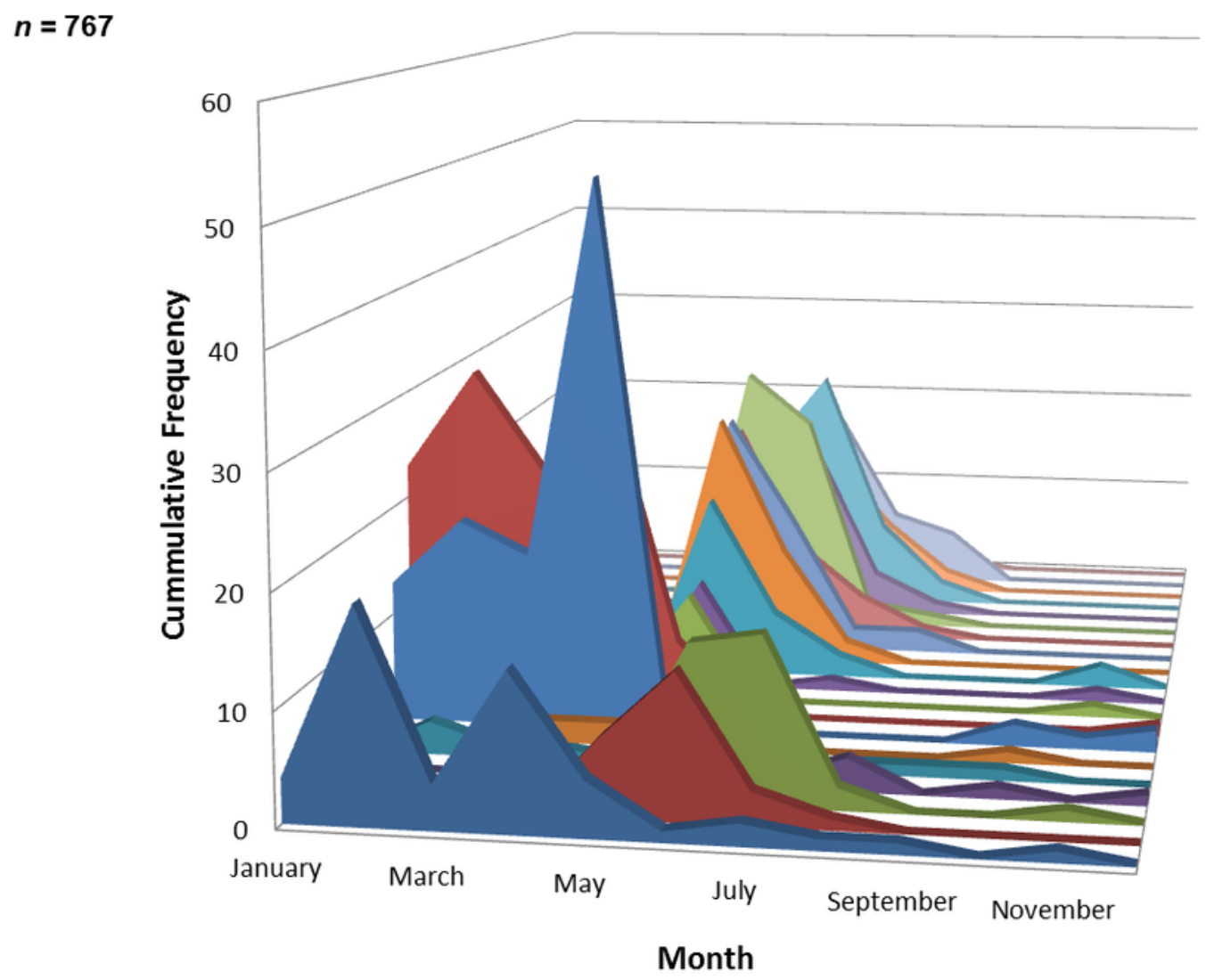

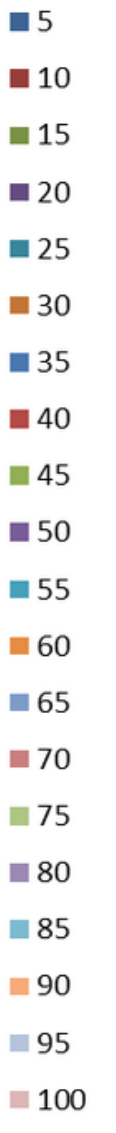


5

Number of ladyfish collected by standard length $(\mathrm{mm})$ in Volusia County, Florida during 1993 through 1995.

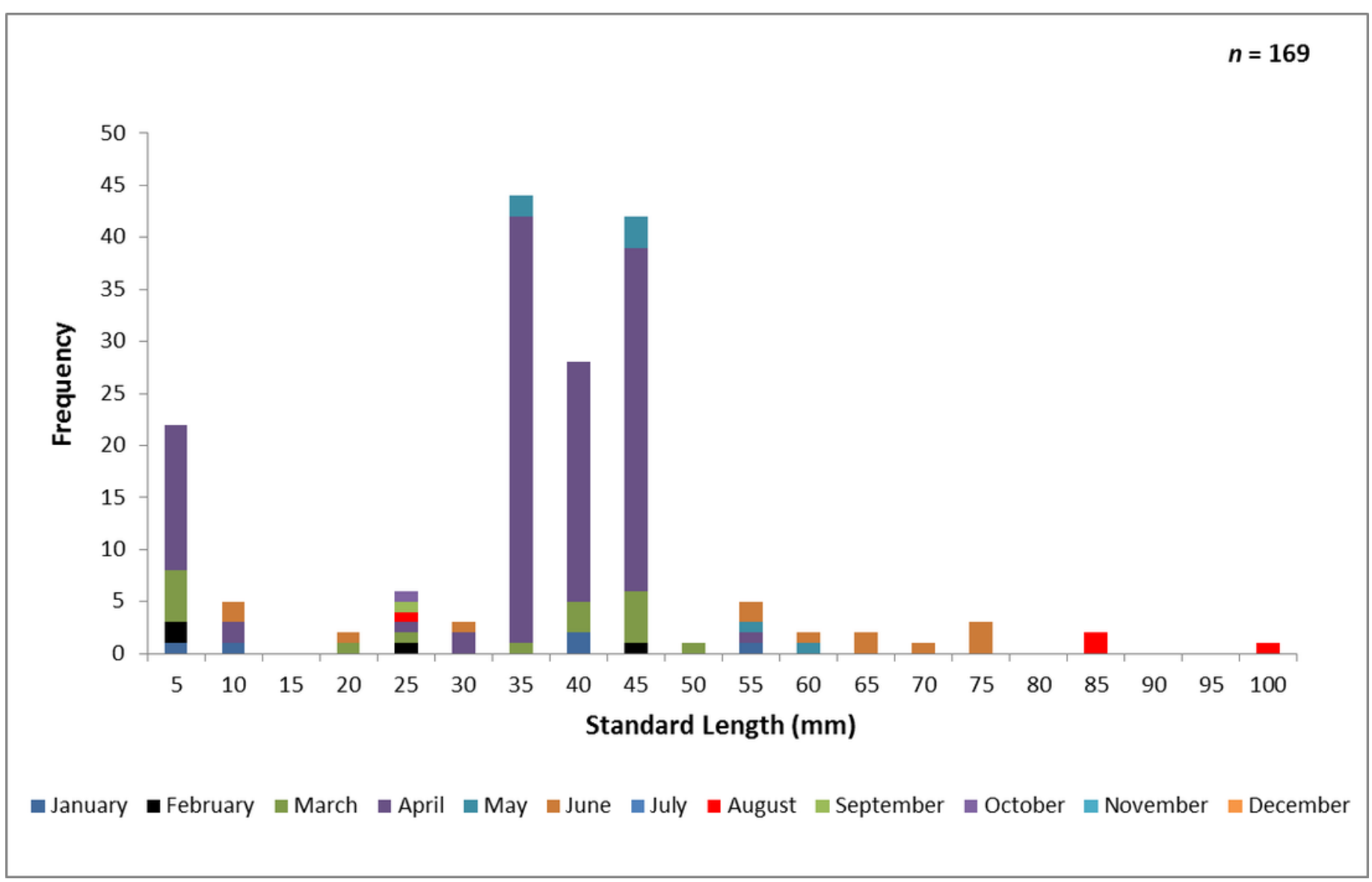


6

Number and size of ladyfish collected by month in Volusia County, Florida during 1993 through 1995.

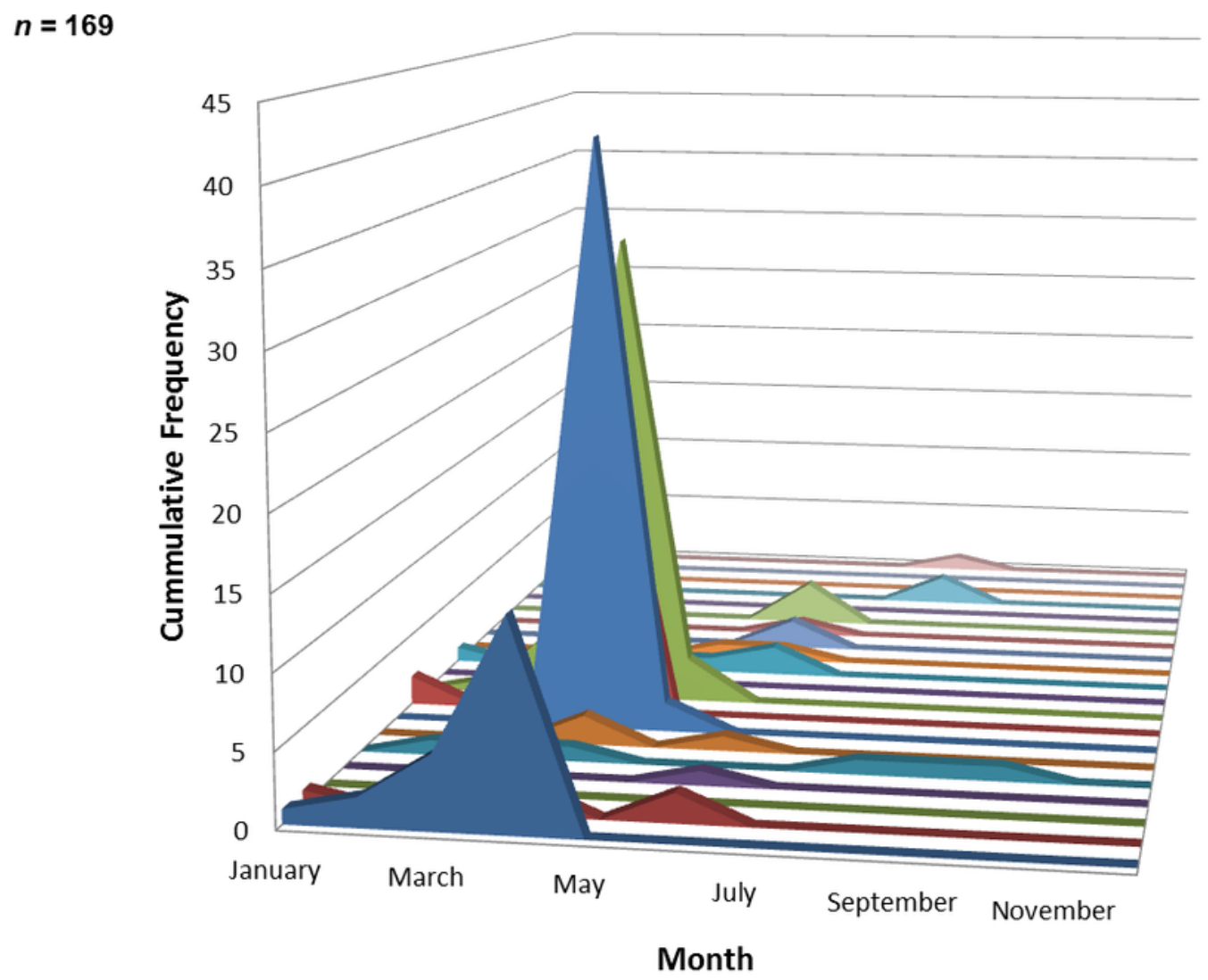


7

Annual mean growth of juvenile ladyfish collected in the Indian River Lagoon, Florida during 1991 through 1995.

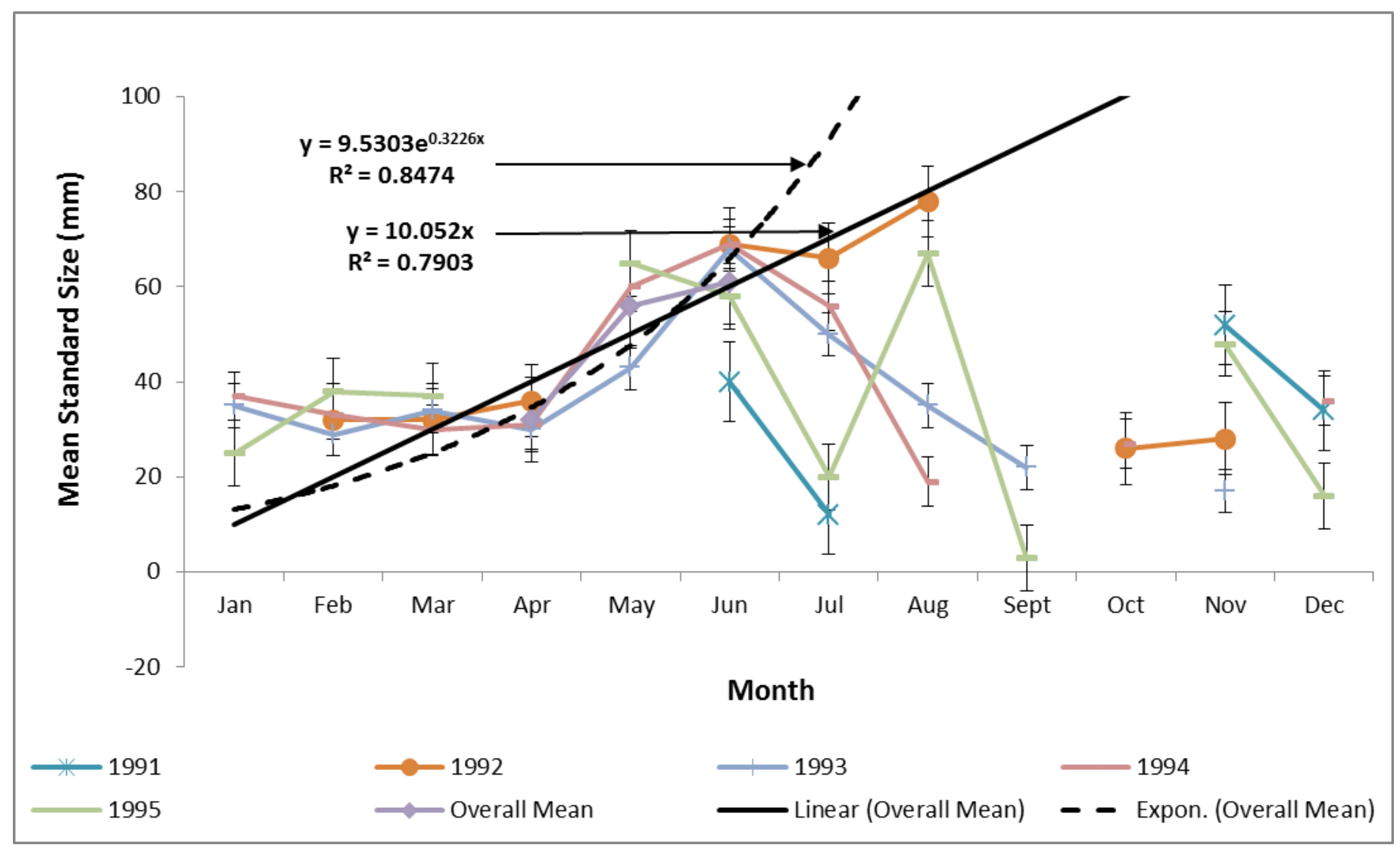


8

Annual mean growth of juvenile ladyfish collected in Volusia County, Florida during 1993 through 1995.

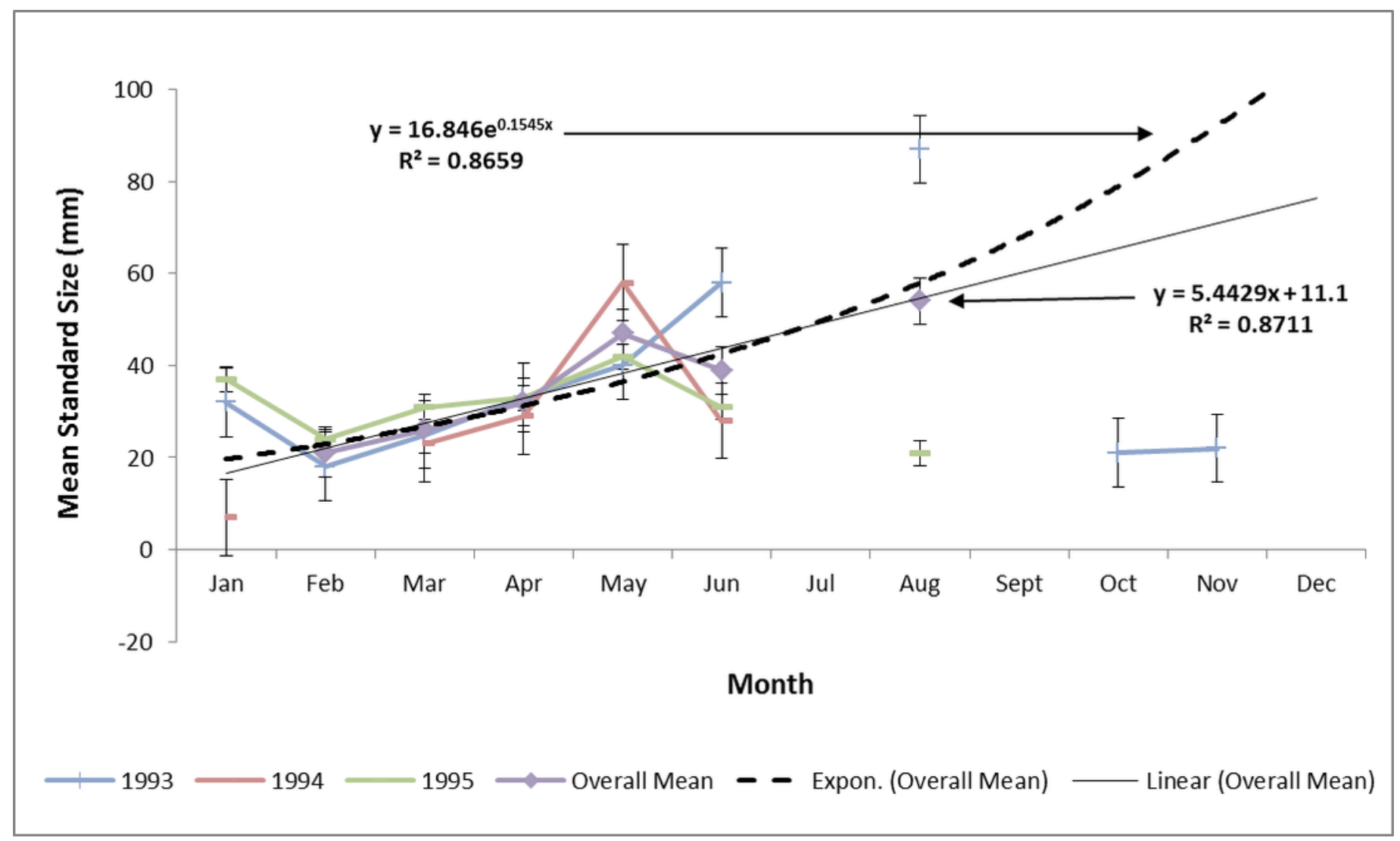


9

Overall mean growth of juvenile ladyfish collected in the Indian River Lagoon and Volusia County, Florida during 1991 through 1995.

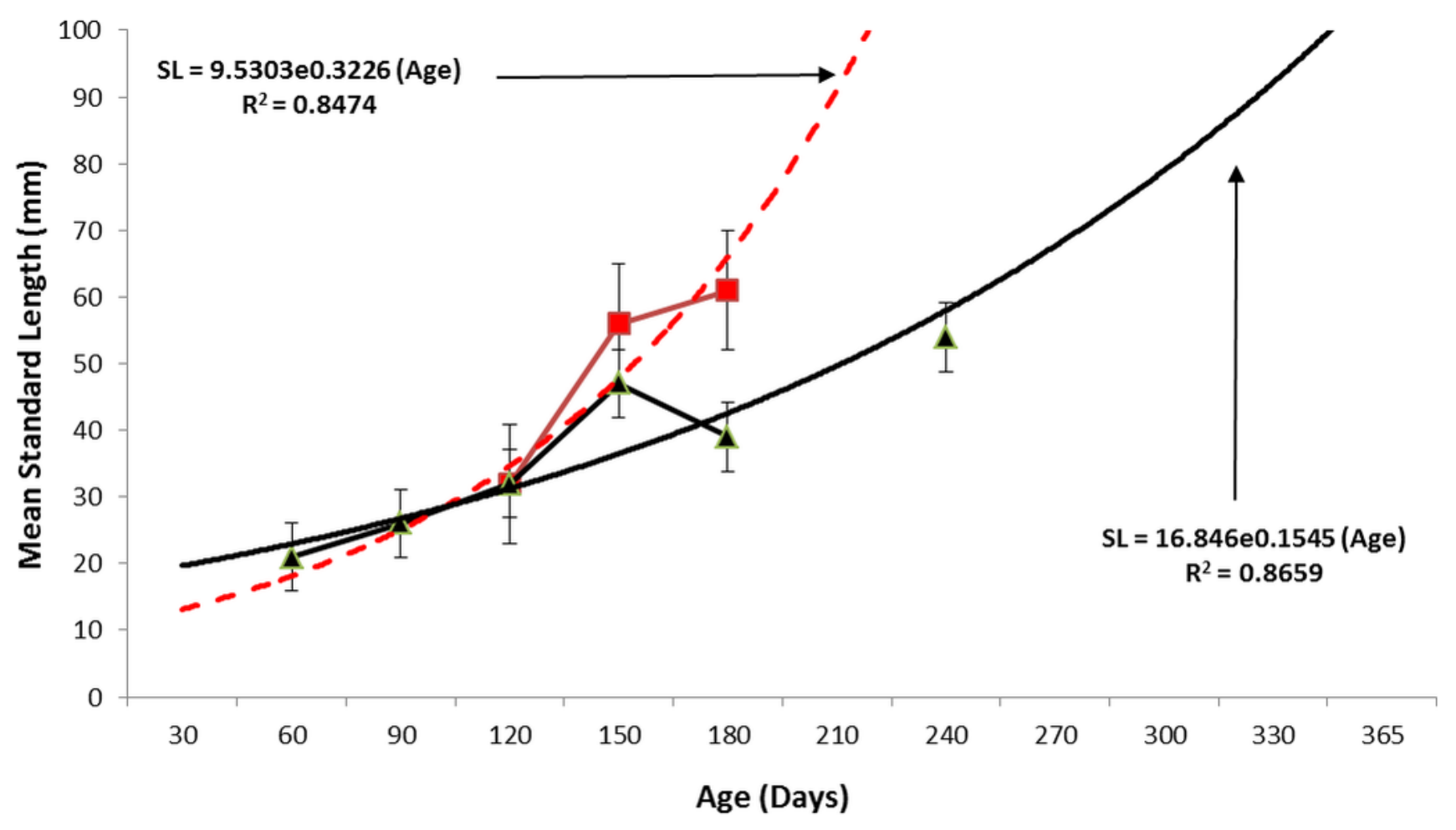

$\longrightarrow$ Indian River Lagoon $\longrightarrow$ Volusia County $\quad-$ Expon. (Indian River Lagoon)

Expon. (Volusia County) 


\section{Table $\mathbf{1}$ (on next page)}

Corrected and non-corrected juvenile ladyfish growth rates and size-at-age 1 (without compensating for time required for leptocephalus to metamorphosis from egg to juvenile) based on length-frequency

Corrected and non-corrected juvenile ladyfish growth rates and size-at-age 1 (without compensating for time required for leptocephalus to metamorphosis from egg to juvenile) based on length-frequency analysis by location. The annual mean growth rate and size-atage 1 was estimated by pooling the data for each location. The $y$-intercept of the exponential regression formula was corrected to $21 \mathrm{~mm} \mathrm{SL}$ to better reflect natural growth (shaded cells). Locations are as follows: Indian River Lagoon (IRL), Tampa Bay (TB), Volusia County (VC [Tomoko River Basin, Ponce de Leon Inlet, and Mosquito Lagoon complex]), and Little Manatee River (LMR). Data for TB and LMR was reported by Levesque (2014). 
Table 1. Corrected and non-corrected juvenile ladyfish growth rates and size-at-age 1 (without compensating for time required for leptocephalus to metamorphosis from egg to juvenile) based on length-frequency analysis by location. The annual mean growth rate and size-at-age 1 was estimated by pooling the data for each location. The y-intercept of the exponential regression formula was corrected to $21 \mathrm{~mm}$ SL to better reflect natural growth (shaded cells). Locations are as follows: Indian River Lagoon (IRL), Tampa Bay (TB), Volusia County (VC [Tomoko River Basin, Ponce de Leon Inlet, and Mosquito Lagoon complex]), and Little Manatee 6 River (LMR). Data for TB and LMR was reported by Levesque (2014).

\begin{tabular}{|c|c|c|c|c|c|c|c|c|}
\hline \multirow[t]{2}{*}{ Year } & \multicolumn{4}{|c|}{ Growth Rate (mm/day) } & \multicolumn{4}{|c|}{ Size-at-Age 1 (mm SL) } \\
\hline & TB & IRL & $\mathrm{VC}$ & LMR & TB & IRL & $\mathrm{VC}$ & LMR \\
\hline 1988 & - & - & - & $\begin{array}{l}0.0001 \\
0.0259\end{array}$ & - & - & - & $\begin{array}{l}0.0449 \\
9.5\end{array}$ \\
\hline 1989 & $\begin{array}{l}1.76 \\
0.9175\end{array}$ & - & - & $\begin{array}{l}3.976 \\
0.5658\end{array}$ & $\begin{array}{l}643.2 \\
334.9\end{array}$ & - & - & $\begin{array}{l}1451.5 \\
206.5\end{array}$ \\
\hline 1990 & $\begin{array}{l}1.41 \\
0.5671\end{array}$ & - & - & $\begin{array}{l}0.0382 \\
0.1284\end{array}$ & $\begin{array}{l}515.2 \\
207.0\end{array}$ & - & - & $\begin{array}{l}13.9 \\
46.9\end{array}$ \\
\hline 1991 & $\begin{array}{l}0.98 \\
0.4123\end{array}$ & $\begin{array}{l}0.1102 \\
0.0986\end{array}$ & - & - & $\begin{array}{l}358.2 \\
150.5\end{array}$ & $\begin{array}{l}40.2 \\
35.9\end{array}$ & - & - \\
\hline 1992 & $\begin{array}{l}0.58 \\
0.4452\end{array}$ & $\begin{array}{l}0.1173 \\
0.1172\end{array}$ & - & - & $\begin{array}{l}211.5 \\
162.5\end{array}$ & $\begin{array}{l}42.8 \\
42.8\end{array}$ & - & - \\
\hline 1993 & $\begin{array}{l}11.78 \\
0.4378\end{array}$ & $\begin{array}{l}0.0711 \\
0.1132\end{array}$ & $\begin{array}{l}0.0980 \\
0.1224\end{array}$ & - & $\begin{array}{l}4301.3 \\
159.8\end{array}$ & $\begin{array}{l}25.9 \\
41.3\end{array}$ & $\begin{array}{l}35.8 \\
44.7\end{array}$ & - \\
\hline 1994 & $\begin{array}{l}2.74 \\
0.6693\end{array}$ & $\begin{array}{l}0.1074 \\
0.1339\end{array}$ & $\begin{array}{l}0.9934 \\
0.1568\end{array}$ & - & $\begin{array}{l}1001.1 \\
244.3\end{array}$ & $\begin{array}{l}39.2 \\
48.8\end{array}$ & $\begin{array}{l}362.8 \\
57.3\end{array}$ & - \\
\hline 1995 & $\begin{array}{l}1.20 \\
0.5304\end{array}$ & $\begin{array}{l}0.0542 \\
0.0754\end{array}$ & $\begin{array}{l}0.0630 \\
0.1224\end{array}$ & - & $\begin{array}{l}436.8 \\
193.6\end{array}$ & $\begin{array}{l}19.8 \\
27.5\end{array}$ & $\begin{array}{l}23.0 \\
44.7\end{array}$ & - \\
\hline
\end{tabular}




\section{Table 2 (on next page)}

Juvenile ladyfish growth rates and size-at-age 1 based on length-frequency analysis in Florida waters by location. For comparison purposes, the direct method growth rate determined by captive rearing

Juvenile ladyfish growth rates and size-at-age 1 based on length-frequency analysis in Florida waters by location. For comparison purposes, the direct method growth rate determined by captive rearing (Levesque, 2014) is shown along with available ladyfish age and growth estimates from previous studies (Alikunhi \& Rao, 1951; Gehringer, 1959; McBride et al., 2001). The overall mean growth rate and size-at-age 1 was estimated by pooling the data for each location. The $y$-intercept of the exponential regression formula was corrected to $21 \mathrm{~mm}$ SL to better reflect natural growth (shaded cells). Locations are as follows: Indian River Lagoon (IRL), Tampa Bay (TB), Volusia County (VC [Tomoko River Basin, Ponce de Leon Inlet, and Mosquito Lagoon complex]), and Little Manatee River (LMR). Data for TB and LMR was reported by Levesque (2014). 
2 Table 2. Juvenile ladyfish growth rates and size-at-age 1 based on length-frequency analysis in Florida waters by location. For comparison purposes, the direct method growth rate determined by captive rearing (Levesque, 2014) is shown along with available ladyfish age and growth estimates from previous studies (Alikunhi \& Rao, 1951; Gehringer, 1959; McBride et al., 2001). The overall 5 mean growth rate and size-at-age 1 was estimated by pooling the data for each location. The y-intercept of the exponential regression 6 formula was corrected to $21 \mathrm{~mm}$ SL to better reflect natural growth (shaded cells). Locations are as follows: Indian River Lagoon 7 (IRL), Tampa Bay (TB), Volusia County (VC [Tomoko River Basin, Ponce de Leon Inlet, and Mosquito Lagoon complex]), and Little 8 Manatee River (LMR). Data for TB and LMR was reported by Levesque (2014).

\begin{tabular}{|c|c|c|c|c|c|c|c|c|}
\hline \multirow[t]{2}{*}{ Age Determination Method } & \multicolumn{4}{|c|}{ Growth Rate (mm/day) } & \multicolumn{4}{|c|}{ Size-at-age $1(\mathrm{~mm} \mathrm{SL})$} \\
\hline & TB & IRL & $\mathrm{VC}$ & LMR & TB & IRL & $\mathrm{VC}$ & LMR \\
\hline Present Study: Length- & 1.11 & 1.25 & 0.2947 & 1.04 & 403.6 & 457.5 & 107.6 & 380.9 \\
\hline $\begin{array}{l}\text { Frequency Analysis } \\
\text { (data pooled) }\end{array}$ & 0.9101 & 0.4356 & 0.2356 & 0.3882 & 332.2 & 156.0 & 80.0 & 141.7 \\
\hline Levesque (2014) & & & 0.8134 & & & & $29 c$ & \\
\hline Alikunhi \& Rao (1951) & & & 0.78 & & & & 28 & \\
\hline Gehringer (1959) & & & 0.63 & & & & 225 & \\
\hline McBride et al., (2001) & & & $5479-0.8$ & & & & 200 & \\
\hline
\end{tabular}

